Loïse Lenne

\title{
The Premises of the Event
}

Are architectural competitions incubators for events?

\begin{abstract}
Around 1980, two important competitions were launched on both sides of the Channel. One led to the Grande Arche in La Défense (Johann Otto von Spreckelsen, 1982-1989) and the other to the Lloyd's building of London (Richard Rogers Partnership, 1977-1986). Recalling the history of these two projects, we will try, in this article, to show how the programmes, their formulation, the methods used and, above all, the culture of the various actors influenced both the decisions and the built results. At the end of the paper, we propose to see these buildings as events. Based on the analysis of these competitions, we will show that these buildings can then be considered as belonging to two different categories - historical and spatial event - that we will define.
\end{abstract}

Keywords: Competition, Programme, Jury, Client, Event, Grande Arche of La Défense, Lloyd's of London

\section{Introduction}

Around 1980, two competitions in two of the main financial places of Western Europe - the City of London and La Défense, the financial district just outside of Paris - led to the commission of two important office high-rises, which were to become the Lloyd's building (Richard Rogers Partnership, 1977-1986) and the Grande Arche de La Défense (Great Arch of La Défense; Johann Otto von Spreckelsen, 1982-1989) and have gone down in history. The similarity of their programmes, their location in financial districts, their proximity in time, place and even height (95 m and $111 \mathrm{~m}^{1}$ ), although not in surface, make the two case studies interesting to compare (Figure 1).

The two competitions also share the quality of having been largely covered in the architectural media. Over fifty articles about the Lloyd's building were published in French and British architectural magazines from 1977 to 1988. Several of them were from special issues about the City of London (which was seen as a changing area thanks to the new building) or even about the building itself, like the Architectural Review of October 1986 (Figure 2), something quite unusual in the history of the journal. To some, Lloyd's was "the most ambitious office building in Europe" (Charalabidis and Meurice, 1981), to others, "the most exciting architectural statement of the moment" (Richard Rogers + Partners. Lloyd's new building, 1984).

There were fewer articles in the architectural press about the Grande Arche, but there were several issues about Mitterrand's projects in Paris (for example, Davey, 1989) as well as a great number of articles about Jean Nouvel's unbuilt Tour sans fins (Tower without Ends), which always mentioned Spreckelsen's building. Hundreds of short articles have also been found about the project in the general press. However, the large media coverage is only one of the noticeable aspects of the two projects. 

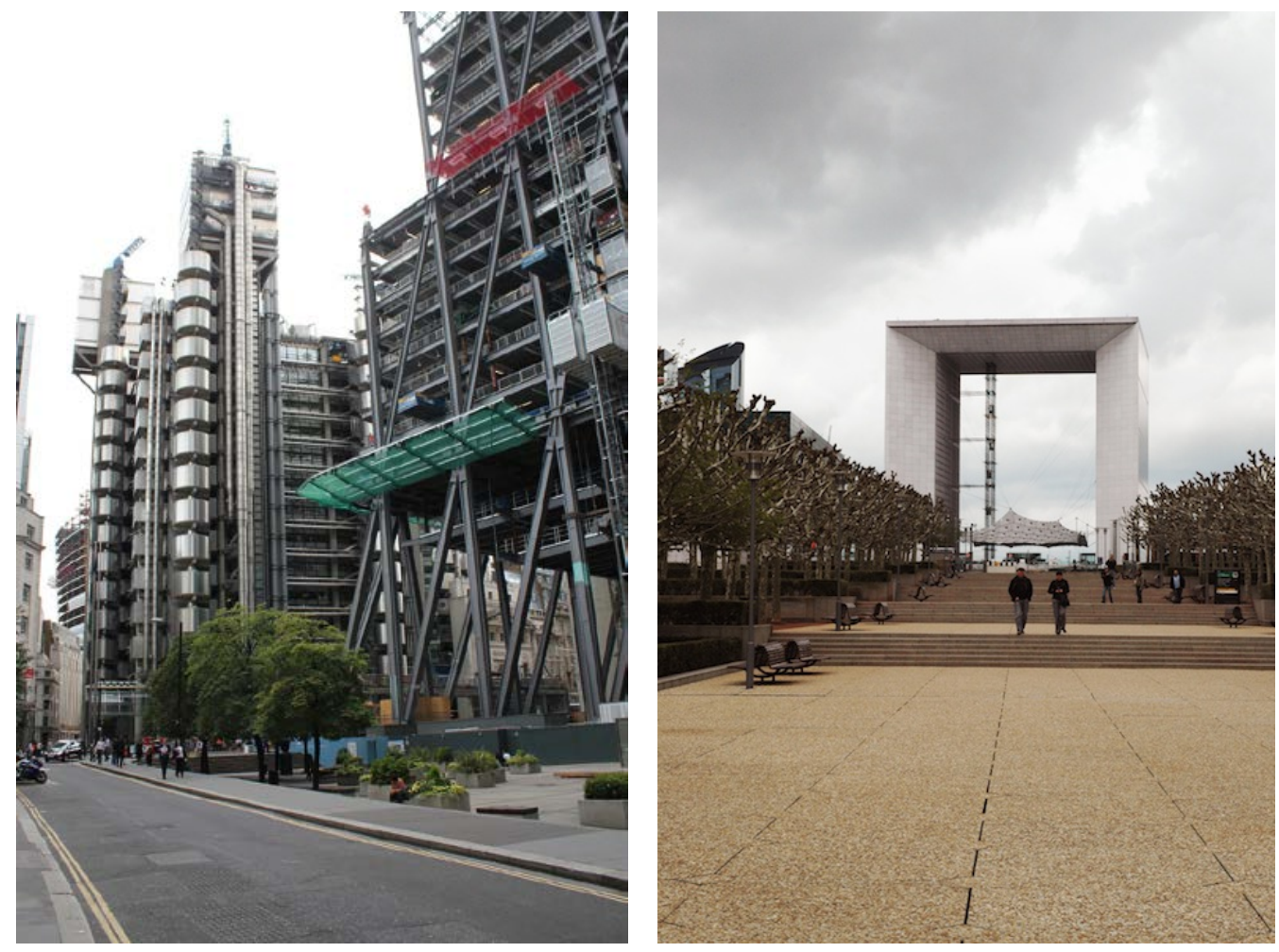

Figure 1: The two case studies. Left: Lloyd's of London. Outside view from St. Mary Axe (the building site on the right is 122, Leadenhall Street, by Rogers Stirk Harbour and Partners (RSH+P)). Right: The Grande Arche on the royal axis. Photographs: Loïse Lenne, September 2012 and 2010.
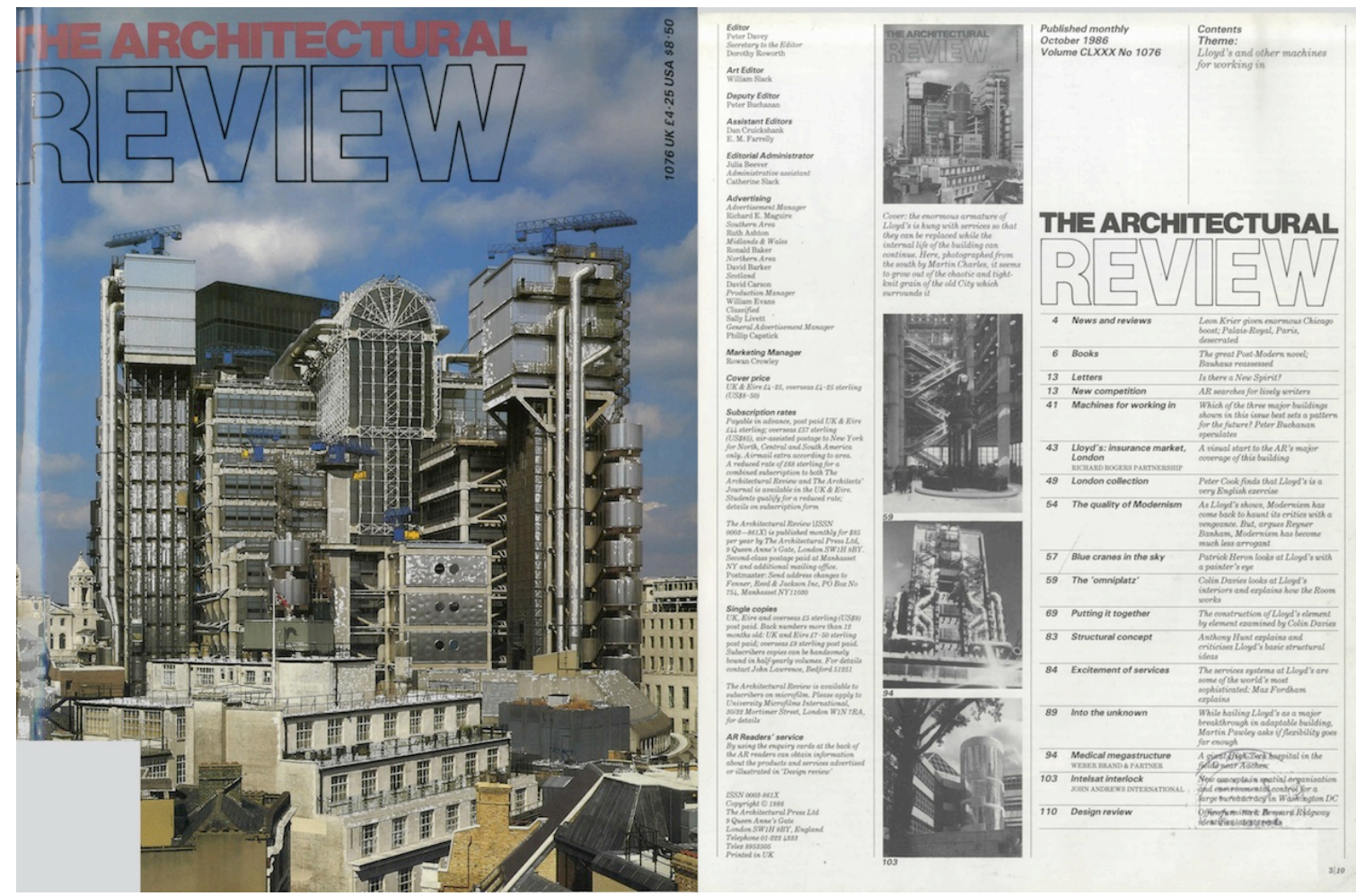

Figure 2: The Architectural Review's special issue on the Lloyd's building. Front cover and table of contents (Davey, 1986). 
Lloyd's was "the biggest private commission in London since the end of the war" (Fillon, 1986). The Grande Arche was part of one of the most important architectural plans of the 20th century in France: the grands travaux (great projects) of President Mitterrand. The two would have to deal with a traditional context. One in a country where the Royal Family is allowed to take a - very conservative (Fillon, 1986) - stand on architecture, something that Rogers has always fought against (Rogers, 1988). The other because it is located on the major axis of Paris, sometimes called the "royal axis", which has always been seen as a heritage to preserve.

The shared level of importance and link to tradition also reveal a crucial cultural opposition between the two projects, which can be found at every level of the competition process: the liberal British system, based on private initiative, versus the regulated and public French system, where decisions are taken in the highest spheres. The two case studies will therefore be investigated here in view of their context in order to reveal the two different cultures and how they influenced the course of the event and the built result. In the first part, we will detail the case of the Lloyd's building - unveiling an unusual competition - and analyse the way in which the building is perceived today. In the second part, we will describe the case of the Grande Arche with even more detail thanks to various original documents. In the last part, we will look at the two projects as architectural events and see how the creation context of these projects - made up mostly of the competition - influenced the type of event that they would become.

This research was undertaken with the help of archives, particularly those from the Établissement public pour l'aménagement de la région de la Défense (EPAD; Public Agency for the Development of La Défense), which allowed us to gather large amounts of data about the Grande Arche and the competition. ${ }^{2}$ Little is available for the Lloyd's building due to the fact that it is owned by a private company. It will thus be analysed through the data that could be found - mainly articles and books about it and visits to the building as well as interviews with various persons around the project or the City (see the full list at the end of the paper).

\section{The Lloyd's building: the project (and) history}

Lloyd's insurance company has developed an atypical way of functioning since its origins in the 17th century. It is very attached to its traditions and to its history. Originally a mere coffee house (Figure 3a), ${ }^{3}$ it has now become a major British institution. Its room has grown much bigger but has kept its name - today, the "Room" is the place where the brokers do their business, and the design of the "boxes" where they sit is based on the former coffee tables (Lloyd's, 2008, 2011).

At the end of the 18th century, the operation took the form of a company and moved to the Royal Exchange, the heart of London trade. In this official recognition may lie the starting point of the importance of the institution for London, England, and all the way to the Crown. When it moved to its first own building by the architect Sir Edwin Cooper (Figure 3b), King George V and Queen Mary came to inaugurate it in person. For the inauguration of its second building in 1957, Queen Elizabeth gave a speech where she recalled the story of the coffee house before an amused crowd. ${ }^{4}$ For Richard Rogers' building, the Queen came on two different occasions - for the laying of the first stone, and for the topping out (Richard Rogers + Partners. Lloyd's new building, 1984). The importance of the institution was then clearly perceived, notably by the municipal services. According to Peter Wynne Rees, the current Planner Officer for the City, the company then had even more influence than today, so it was "as if the Queen was asking for a building permit - no matter what her taste, no one would ever say no” (Rees, 2012). 


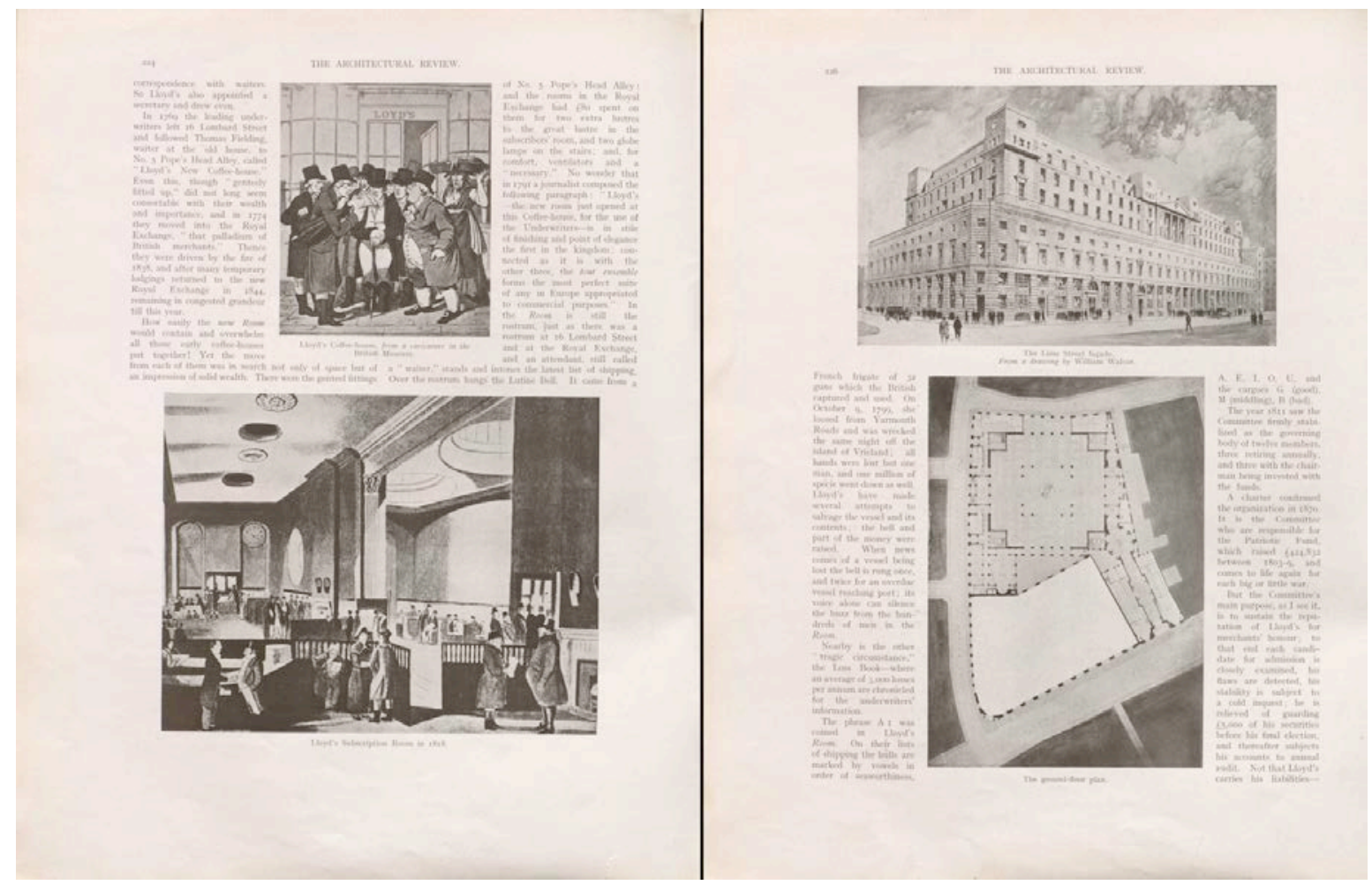

Figure 3a (left): Lloyd's locations before its first own building: Lloyd's Coffee House (from a caricature in the British Museum) and Lloyd's Subscription Room in 1918 at the Royal Exchange.

Figure 3b (right): Lloyd's first building by Sir Edwin Cooper (1928). The Lime Street Façade, from a drawing by William Walcot (Stratton, 1928).

It seems that the 1928 building was not the best example of Cooper's architecture and that his designs had not been properly executed (Blackmore, 1990, p. 109). The building especially hadn't been planned large enough because of a failure to anticipate the future evolution of the company, and the lack of space, especially in the Room, forced the company to move again in 1958. In spite of all this, Lloyd's chose Terence Heysham, who had taken over Cooper's agency, for the new project. The choice says a lot about the institution - loyal to its tradition and little inclined to change.

But as early as 1975, Lloyd's was confronted with the problem of space once again. The employees had probably got "tired of moving" (Rogers, 2012) since some of them had already moved before. Moreover, the brokers were often very attached to their "boxes" (their desks), which solidified their position in the company and which they arranged little by little to suit their routines. So there had to be a good reason to move again.

\section{One clear goal only}

In 1977, the situation was critical and the work urgent, but Lloyd's Committee did not want to make the same mistake. It seems that the construction of the other two buildings had been necessary to realise that the problem had not been well posed.

Ian Findlay, ${ }^{5}$ deputy chairman of Lloyd's, thus contacted the Royal Institute for British Architects (RIBA). Considering the importance of the client, Gordon Graham, ${ }^{6}$ its president, decided to personally take charge. After only a few meetings over lunch and faced with a number of uncertainties, Graham suggested a limited competition between invited architects. Moreover, he warned Lloyd's that it had to be ready to commit a certain amount of money, before anything else, for choosing between them (Richard Rogers and Partners. Architecture and the program: Lloyd's of London, 1980). The consulting cost the company 
some 100,000 pounds, of which the architects who were finally not retained received 10,000 each $^{7}$ (Appleyard, 1986, p.236).

At first, Graham proposed only British architects. Foster and Rogers (then Piano + Rogers) were selected because he considered them "the finest of British architecture" (Appleyard, 1986, p.237). Arup Associates were selected, too - they had just finished building very well-received offices for Lloyd's in Chatham and were therefore seen as frontrunners (Appleyard, 1986, p.237). However, Lloyd's insisted on having other nationalities in the running - the Chinese American Ieoh Ming Pei, the Canadians Webb Zarafa Menkes Housden and the French Serete, which the board chose itself, were added to the list.

As President of the RIBA, Graham could have recommended organising a more open competition, but such a traditional strategy seemed impossible because of the uncertainties surrounding the future building, making the writing of a detailed programme impossible. So he proposed an organisation that was "more ... not traditional [such as an open competition like the one for the Pompidou Centre], but neither Norman Foster nor [Richard Rogers] had ever built an office building before, so it was moderately open. They looked at about sixty projects [of reference], then they came down to six finalists, which were very diverse" (Rogers, 2012).

The meetings between Graham and Findlay established that the problem was not so much the new building surface area as its flexibility (Appleyard, 1986, p.236). The pages of the programme are not known to us, but the importance of the flexibility criteria was confirmed by Rogers in an article published at the time where he analysed the demands. Besides the obvious answer to the demands of the client and the market as well as the new idea of being able to rent a part of the building to other companies, and of course the quality of the building itself, the guiding principle was indeed flexibility. The term appeared twice in the six key points mentioned: first, for the size of the Room, which had to be able to be modified easily according to the use demanded of it; and second, in the last central point - "to optimise the use of available land, allowing a high degree of flexibility and choice of alternative uses during design, construction, and occupation of the building” (Lloyd's of London, 1987).

\section{Programme versus process}

The programme for the Lloyd's building was not really a programme in the sense that it was not a detailed description of the needs of the future building, its organisation, and the various areas needed. This was confirmed during the presentation meetings organised by the Committee: the request that was most clearly expressed was that submissions should not be projects, but strategies. As Courtenay Blackmore, ${ }^{8}$ Head of Lloyd's Administration and of the project, admitted: “we didn’t really know what we wanted to do" (Waters, 1985). This could have given the architects a lot of freedom, but they were obviously confused by it. Serete, for example, handed in very elaborate designs, going into every last detail, which caused the agency to be immediately eliminated (Appleyard, 1986, p.238).

The way the competition was organised was in itself a strategy. Contrary to an anonymous system, Lloyd's Committee personally explained the stakes of the competition to the different contestants. It met with the two finalists, Rogers and Arup Associates, at least three times. The difference between this procedure and a more traditional one is a question of philosophy. The idea here was that the more the architect knew the client, including his personality, the better his submission would be. Blackmore even explains that the problem with an anonymous competition is that the client could hire an architect whose personality would end up a poor fit (Blackmore, 1990, p. 38). He was thus very pleased with the system they chose: "the formula proved its worth since at the end the interview panel had a very clear 
idea of each practice's attitude and beliefs, comprehension of an approach to the problem, and the sort of people they were ... It was vital for Lloyd's not to select an architect on the basis of an outline design ... . the method adopted proved to be very successful” (Richard Rogers and Partners. Architecture and the program: Lloyd's of London, 1980). Norman Foster was in fact eliminated because he was considered "too much of a loner who would carry the entire project inside his own head” (Appleyard, 1986, p.238), a consideration very much about the person and not his architecture.

Such a strategy also reveals the "specific approach" of the advisor Graham (Rogers, 2012) or, in other words, his very contextual approach to competitions. As a matter of fact, he also advised the Hong Kong and Shanghai Banking Corporation on the construction of its headquarters (Norman Foster, Hong Kong, 1979-1985) a little later and used a different process there (a limited competition as well but with the demand for designed projects) according to the clients' needs. It also reveals the somehow liberal approach that is described by other members of the Royal Institute of British Architects (RIBA) (Strong, 2012), which is probably attributable to cultural matters.

More generally, it reveals the importance of the client. In fact, Richard Rogers greatly insisted on this point during our talk, citing Courtenay Blackmore, Robert Bordaz, ${ }^{9}$ Peter Green $^{10}$ and Robert Lion. Already, in a 1986 documentary (Wall of Light), he said that important projects such as the Maison de Verre (Pierre Charreau, Paris, 1932) are never possible without a great client and that he himself had had some wonderful ones. John Young, his partner, went so far as to say that Lloyd's development Committee was a better client than the one Rogers had for the Pompidou Centre: "The great thing about Lloyd's is the amount of time and trouble they are prepared to take to contribute to a regular dialogue with the design team" (Waters, 1984). To him, it allowed Rogers to design an even more advanced project (Cooper, 1986). As early as 1981, the RIBA Journal published a file about patronage relating Blackmore's role (Patronage, 1981).

Even though it received the advice it was asking for, Lloyd's Committee always remained the final decision-maker. Ten years or so later, Blackmore published (with the support of the RIBA) a book on his experience as client for many buildings and for the Lloyd's building in particular (Blackmore, 1990). It is unusual for a client to discuss architecture in this manner. The book again highlights the involvement of Lloyd's during the whole process as well as the means put into place from the very beginning all the way to the inauguration in terms of time, people and money.

\section{The two sides of a decision}

No files in Lloyd's archives allow us to precisely analyse the decision process. However, it seems to be commonly acknowledged that Rogers was chosen in part because he worked with Arup (engineering) as consultants. Even though this is a different company from Arup Associates (architecture), who were on good terms with Lloyd's and were also in the final run, several members of the Committee did not quite understand the difference. They apparently thought that by hiring Rogers, they would also get Arup Associates, which seemed like a good way to combine the two (Appleyard, 1986, p.241). This confusion may have contributed to the team's victory. Their nationality may have helped them as well, since Graham "later admitted that he very much hoped one of the UK practices would be successful” (Blackmore, 1990, p. 40). 


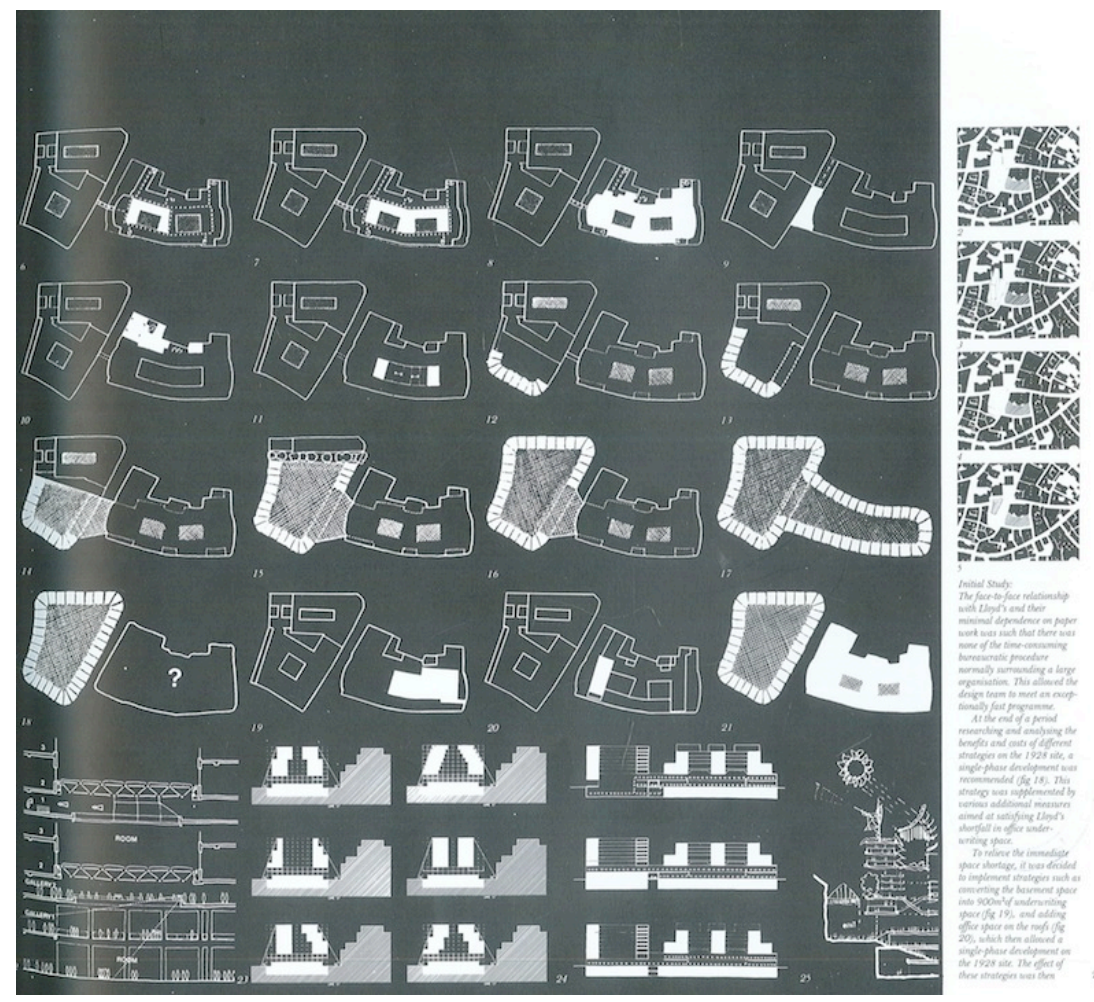

Figure 4: Rogers and Partners' first studies for the Lloyd's building, showing the two sites owned by the firm and the different possibilities, from the rehabilitation of the existing buildings to a total demolition (Richard Rogers and Partners. Architecture and the program: Lloyd's of London, 1980).

Rogers' victory can also be explained by his good understanding of Lloyd's demands - he was in fact the only architect to understand them. His answer was composed of multiplechoice propositions for each step of the project. His first designs showed the different possibilities for the two existing buildings and solutions that went from increasing their size to demolishing one of them completely (Figure 4). He also added more technical sketches, showing what the agency was preparing to offer according to the chosen solution. The atrium, notably, was present - in a different form - from the very first stage (Figure 4, bottom right).

It is hard to say in this case that the jury was able to "conceive" the project, in JeanPierre Chupin's words (Chupin, 2012), because, in fact, it did not ask for one. We could even say that there was no jury as such. On the one hand, the jury was constituted of Lloyd's Committee members (only), advised by Graham. On the other, all the careful steps proposed by Rogers and his team put the Committee - the client, but also the future user - in a situation comparable to a usual commission, where it could discuss the result, or even almost comparable to a participative process, where the architect is chosen more to guide than to design.

But as unusual as this competition was, it still highlights an important phenomenon in a competition process - when an architect identifies with a programme. In his previous key projects, Rogers had faced the issue of flexibility - for the Patscentre (Melbourne, 19761983) and, with Renzo Piano, for the Pompidou Centre (Paris, 1971-1977). This second project was in fact the result of a well-known competition, at least among architects, but not only, because it had given the opportunity to the two very young architects to build an unconventional, high-tech pioneer, oddly-shaped building - a sort of a monster in size and form in the very centre of Paris, much like the Lloyd's in London.

The flexibility theme had then become a key element of Rogers' architecture. He answered it with the extensive use of materials like metal, allowing prefabrication and 
assemblage, but, moreover, with a radical application of the separation between "servant" and "served”, which Louis Kahn had theorised. Just like for the Pompidou Centre, but in an even more expressive manner, the servant parts were placed on the outside of the building. The resulting space is an empty rectangle, to be furnished according to the changing needs of the client. The programme for the Lloyd's seems almost to have been tailor-made for an architect like Rogers, allowing him to put his principles into application. Such a radical attitude made the architect Claude Parent write that the Lloyd's was "the most perfect kid in the family" (Parent, 1986).

The two sides of the decision - the proceedings in this competition and the architect's identification with the programme - both led to the same built result. Their combination helped the birth of what is considered an important achievement. The Royal Fine Arts Commission, though conservative, even "said that it should be one of the most remarkable buildings of the decade" (Richard Rogers + Partners. Lloyd's new building, 1984), an opinion shared by some important critics in the architectural press (for example, Waters, 1984).

\section{A forgotten hero?}

Today, the importance of the Lloyd's building in the architecture of London seems to be acknowledged. Peter Wynne Rees, current planning director of the City, states that "in architectural terms, it did break the mould” (Rees, 2012). Paul Finch, former editor of the Architectural Review and member of the CABE (Commission for Architecture and Built Environment), states that "the Lloyd's building was revolutionary [...] because its architecture was very different from all the things the City had seen at the time [...]” (Finch, 2012). Both agree on the fact that this building opened the way for other towers which would have otherwise probably never existed. These may have also appeared thanks to the work of Peter Rees, who took up his position in 1987.

They also agree on the soundness of the recent Grade 1 (highest grade) listing of the building, ${ }^{11}$ which is rare for a post-war edifice. ${ }^{12}$ Chris Smith, the National Planning Director of English Heritage, is also very pleased about this decision (Smith, 2012). We shall note that the Lloyd's building no longer belongs to the company itself, since the crisis of the 1990s, even though it continues to rent it and will probably do so for several years. ${ }^{13}$ The listing may also have been a way to protect the building from investors who would be less interested in the modern heritage than Lloyd's was.

The importance of the Lloyd's is also pointed out by the fact that the company has celebrated the 25th anniversary of the building and invited Richard Rogers and his partner Mike Davies to give a conference about its architecture before a selected audience. The company's pride in its building, or at least its will to show it, is apparent, even in the words of some more recent recruits (Castro, 2012).

With its height of 96 metres, and even though it was never the highest point in the City, the Lloyd's building was considered very tall in the medieval streets of the borough. Building regulations in London are in fact based on view corridors, areas where height is limited. Some of the major view corridors lead to St Paul's Cathedral and define an area around the axis of Bishopsgate, where there already was a timid cluster of higher buildings before the construction of the Lloyd's (Figure 5a).

The fact that there is no major view to protect has made it possible to develop several towers since. Nowadays, the Lloyd's building seems tiny next to the Shard (RPBW, 2012, $306 \mathrm{~m}$ ) and all the towers built since (Figure 5b and Figure 6). One can then wonder if the Lloyd's influence is of common knowledge. Will a tourist absorbed by the image of the Gherkin across the street (Foster and Partners, 2004, 180 m) see it? 


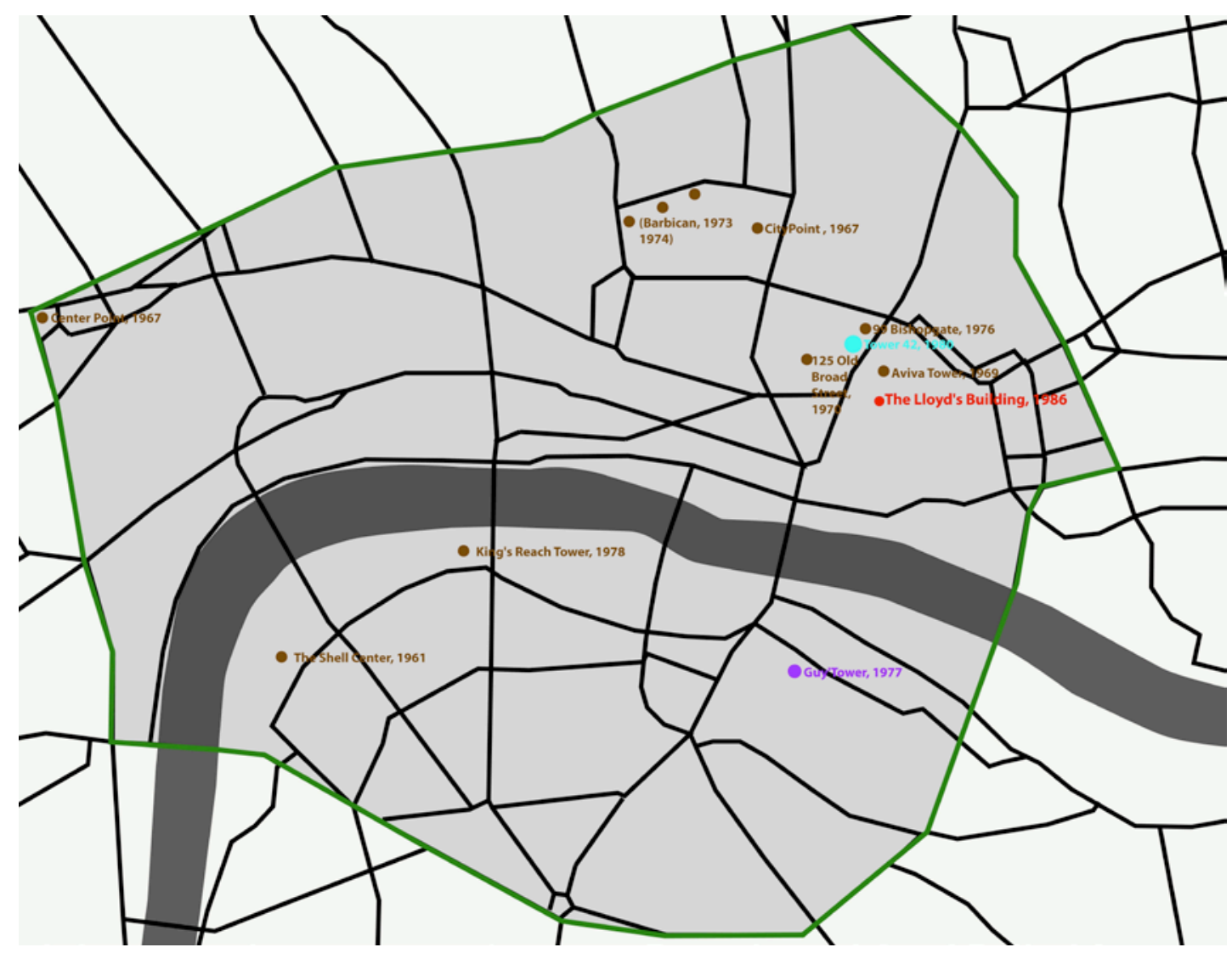

Figure 5a (left): The situation of tall buildings in the City and surroundings before 1986.

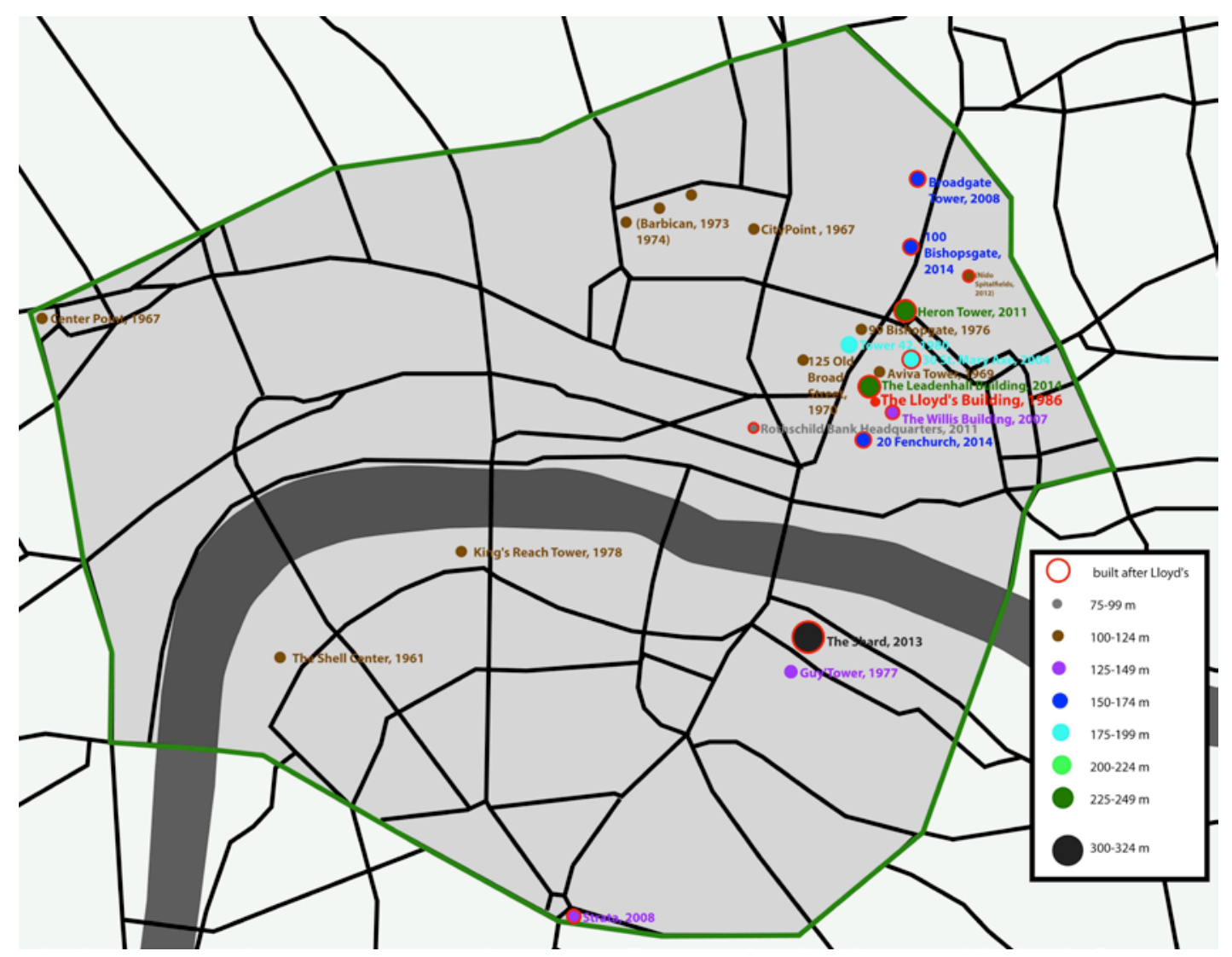

Figure 5b (right): The situation of tall buildings in the City and surroundings in 2012 (Document: Loïse Lenne. Data: Council on Tall Building and Urban Habitat [CTBUH]). 


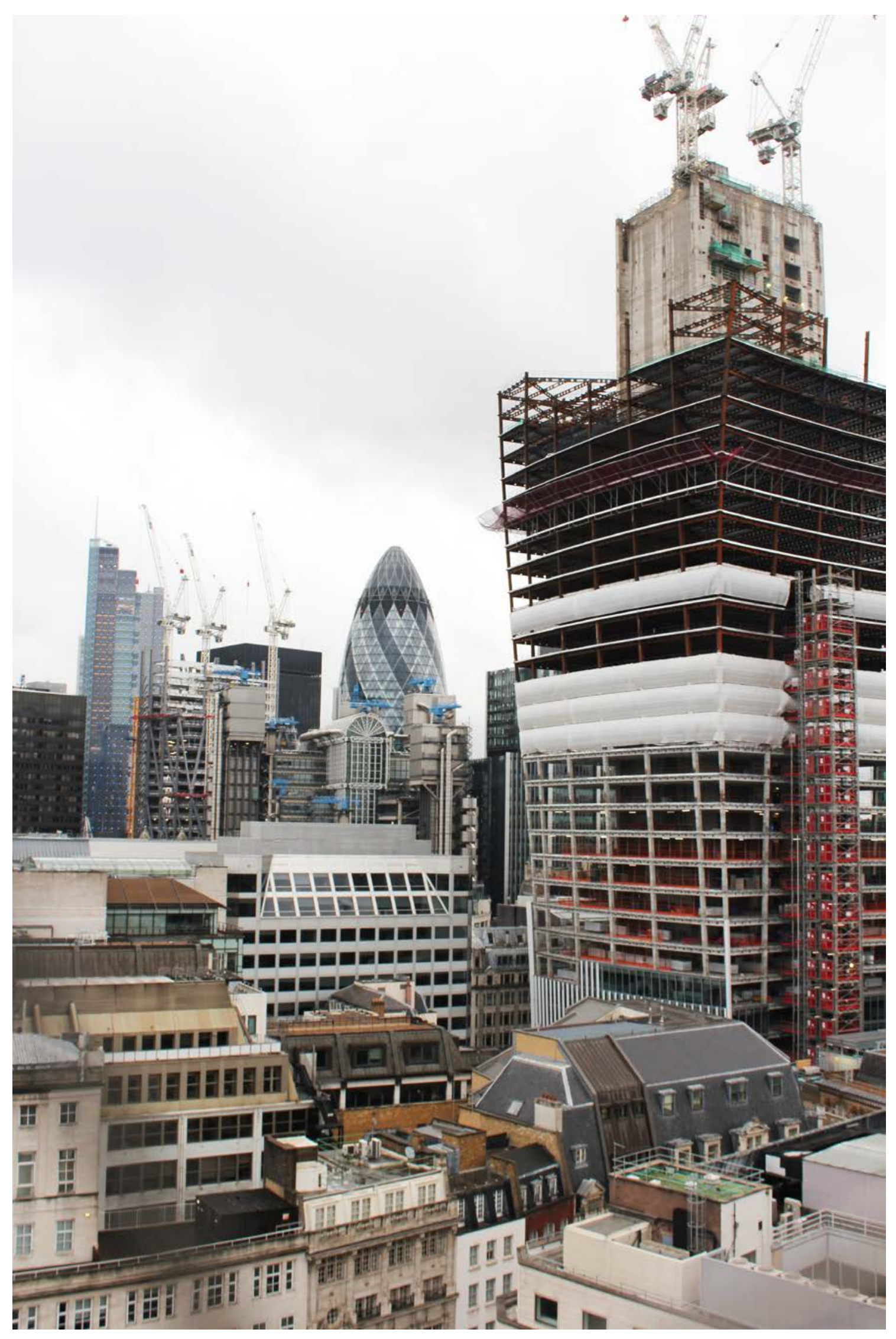

Figure 6: The Lloyd's building, viewed from the Monument, in between more recent towers and construction sites (Photography: Loïse Lenne, September 2012). 


\section{The Grande Arche of La Défense: The Competition (as a) Result}

The Grande Arche competition should first be considered in light of the history of La Défense. The potential of the whole site of La Défense, which is the extension of the Axe royal (Royal Axis) of Paris, was already noted at the beginning of the 20th century (Rouyer, 2012). Public and private projects as well as competitions followed one after the other until the one commissioned to the architects Robert Camelot, Jean de Mailly and Bernard Zehrfuss. In 1958, a public organisation, the Établissement public d'aménagement de la Défense (EPAD), was created in order to take charge of the overall project.

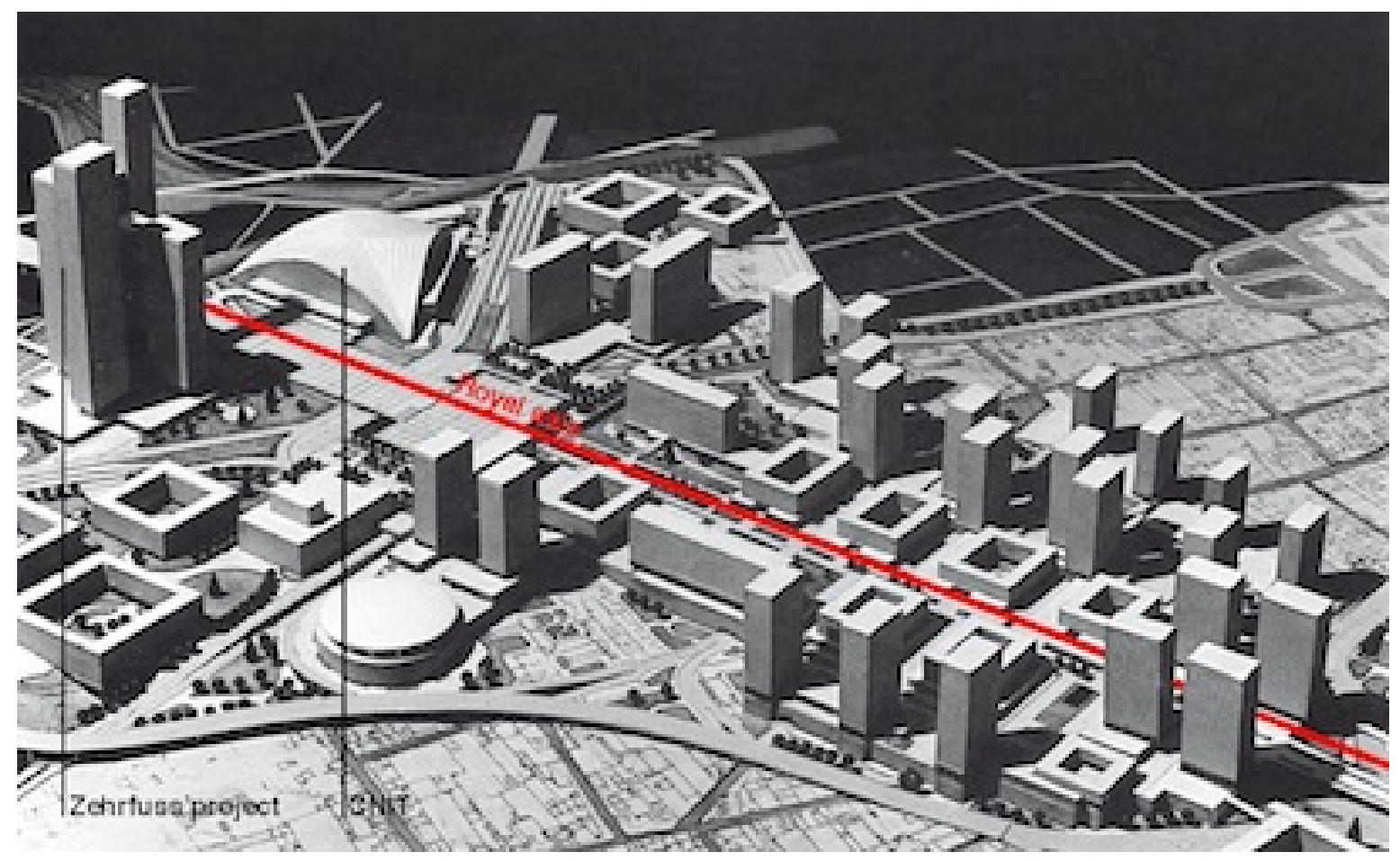

Figure 7: Model of the project for La Défense around 1964.

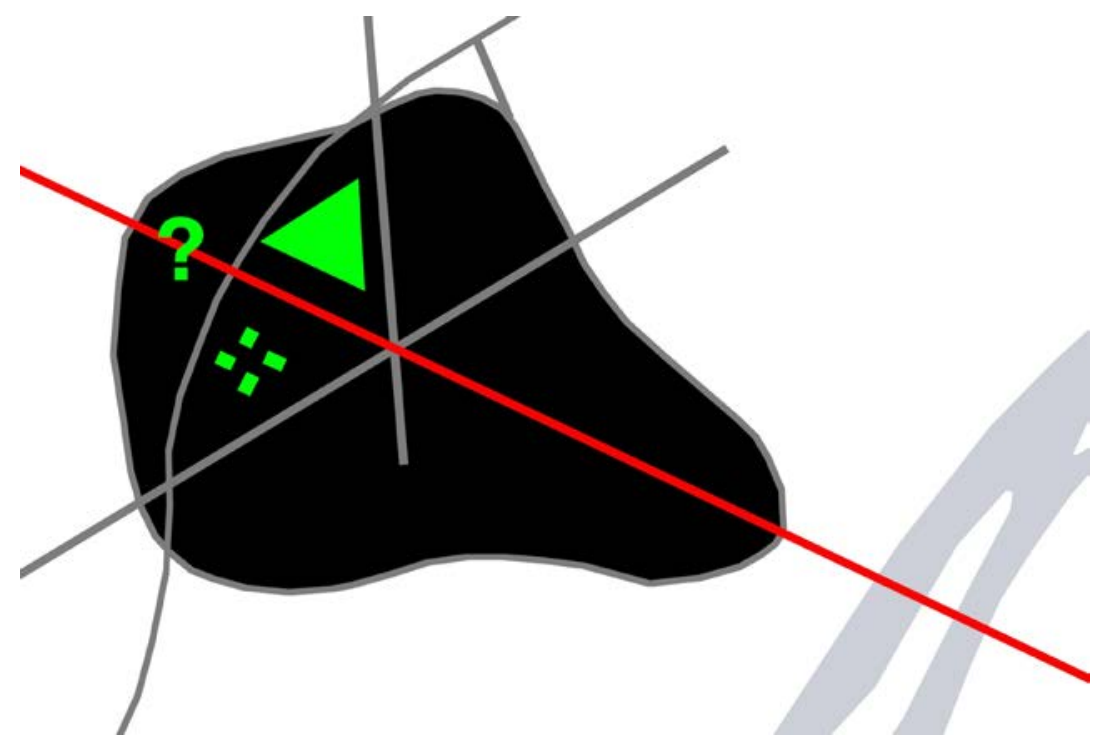

Figure 8: Schematic plan of La Défense as planned in 1964. The roads mark out three sites: one for the CNIT, already built, one for the towers of Zehrfuss, and a third on the Royal Axis (in red) (Document: Loïse Lenne. Data: EPAD/Defacto). 
The plan was typical of an above-ground planning project, symmetrical and centred, including office and housing buildings, each of their own form (Figure 7). In this highly ordered context, built inside the pear-shaped circular boulevard, the CNIT (Centre des nouvelles industries et technologies; Centre of New Industries and Technologies) and its symmetrical site on the other side of the axis became a focal point. Bernard Zehrfuss suggested that the building on the second site be composed of four towers up to 200 metres high. This project opened the way for a number of other projects because it transgressed the original regulated plans. Along with the CNIT and the pear-form of the square, it moved La Défense's centre of gravity over to the west, almost to what was soon going to be known as the Tête Défense, ${ }^{14}$ the highest point of the square, the third point of a triangle formed by the two previously mentioned sites (Figure 8).

When the general plan was decided on, it became possible to focus on the individual projects: in 1969, Ieoh Ming Pei was commissioned by the developer Jean-Paul Aaron to design a building on the site of Zehrfuss' unbuilt towers. The architect proposed twin towers on the Tête Défense instead (Chaslin, 1989): soon, all eyes would turn to this site.

This project forced the EPAD to investigate the now central question of the Tête Défense, and it asked Émile Aillaud to come up with a project as well. Even though he, too, closed off the axis, he proposed two low-rise buildings with reflecting walls. Both projects established the terms of a debate that would last for over 20 years - to close or to open? to reflect the axis? what shape should it take? should it be a companion to the Arc de Triomphe? how high should it be? In the end, the only question that was not asked was the one of the programme itself, when, in fact, placing office buildings on an axis that Parisians considered a public space could cause a problem.

When the two projects were revealed in 1971, controversy ensued, and the EPAD was bound to organise a competition this time. This limited competition, of which Aillaud seemed to remain the likely winner (Rouyer, 2012), did not reach any conclusion. The EPAD continued to consult until 1980 - internally, though - when a nationwide competition was launched. Jean Willerval's compromise project came out the front-runner. He used the idea of reflecting the axis, without closing it off completely - a non-symmetrical building but nevertheless residing on a set-on-axis composition. Moreover, as stipulated by the rules, the building was to be 35 metres high in order to "avoid seeing it through the opening of the Arc de Triomphe from any point whatsoever of the Louvre to the Étoile section of the main axis" (EPAD, 1980a).

The project could have continued its journey until completion, but Jean-Paul Lacaze, ${ }^{15}$ director of the EPAD, "found it preferable to wait" (Lacaze, 1994, p.128) because of the upcoming presidential election. The question of the Tête Défense was becoming political. In fact, François Mitterrand came into office in May 1981 and launched his policy of Grands Travaux (Great Projects), which, with the exception of the Louvre pyramid, would all spring out of competitions. Mitterrand's interest in architecture went far beyond his desire to put his personal imprint on the country, though this, too, was an important criterion, of course. Richard Rogers, who was a member of the jury for the Tête Défense competition, still recalls how impressed he was by Mitterrand's sense of space, interest in the project, and wide knowledge of Paris (Rogers, 2012).

At first, the projects were managed at the Paris region level, and Robert Lion, one of the right-hand men of the President, in charge of the Grands Travaux, remembers "fun times. On the table were the Opera project, the Cité des Sciences (Science Museum), and [...] the Centre for Communication. [...] And all that was done with a map of Paris that we turned in all directions - what will be done at La Villette?, what's for the Bastille?, what about La Défense?, what will be further out?” (Lion, 1994, p. 154). With Lion's help, Mitterrand 
quickly decided to set aside Willerval's project in favour of a "more ambitious and significant” one (EPAD, 1982; Lion, 2012).

The problem of the function of the only one of the Grands Travaux in the suburbs, but, more than that, of the Tête Défense, was finally decided on and a Centre for Communication as well as two Ministries ${ }^{16}$ were planned for the occupation of the site. All these incidents in the course of the project had made the Tête Défense an important stake, and as there had already been several competitions, something somewhat bigger had to be organised, at least to prove that this time the winning project was going to be completed. An international competition was thus launched.

\section{An ambitious organisation}

The competition's organisation directly involved the president and the general director of the EPAD - important managerial people, just like Blackmore for the Lloyd's building. A very large amount of money (two million francs ${ }^{17}$ ) was also set aside for the participants. But in this case, only the prize-winners and honourable mentions received compensation.

An outside organisation, the International Union of Architects (UIA) was called upon for guidance. It seems that this was done more to add yet another token of quality, and maybe to again reassure the architects who were tired of taking part in one competition after another for the same site, than to actually take advantage of the organisation's expertise - unlike the help of the RIBA for the Lloyd's. The choice of the international criteria, for example, was undoubtedly made by President Mitterrand and his team (Lacaze, 1994, p.129) and not as a consequence of the UIA blessing.

Following the French pattern and the rules established by UIA for competitions, it was anonymous. All participants were entitled to send their questions to the client; however, only one file of answers, although quite extensive, was sent back to them. Contact was thus very limited, unlike for the Lloyd's competition.

The jury chosen was international and prestigious, and was presided over by Robert Lion, who immediately took charge. As a former member of the French Ministry of Equipment, he had already studied the question and had "vigorously taken a stand against the 'mediocrity' of Giscard's choice [the Willerval project], a low-rise building, which made it impossible to see the 'small head' (Tête) of la Défense [. . .]” (Lion, 1981).

After a first meeting in October, the EPAD hosted the jury for a week in April on the 44th floor of the Fiat Tower, recently bought by Framatome, who lent the space (Lacaze, 2009). Other places in La Défense had been considered (EPAD, 1983a), but the specially refurbished apartment of the former CEO (EPAD, 1983b) made the prestige of the operation more pointedly clear. In addition, the jury was composed of foreign architects, including Richard Meier, of French architects, including Bernard Zehrfuss, of prominent foreign figures, including the architecture critic Ada Louise Huxtable, and of prominent French figures. ${ }^{18}$

The brief that the nearly 900 candidates received was a large box containing several files, blueprints, and tracing paper for the rendering, which had to be of a specific format, layout, scale and number of documents (Figure 9). The level of detail given was great thanks to the amount of analyses available internally at the EPAD and to the dozens of already designed projects.

The analysis by the technical commission was undertaken afterwards in consequence. Seven pages detailed every aspect of the projects - shape, position, access and surface area, and the general "technical and economic feasibility" (EPAD, 1983c). The amount of work was considerable - each team of analysts was composed of specialists who devoted two to three hours to each project (EPAD, 1983d). 

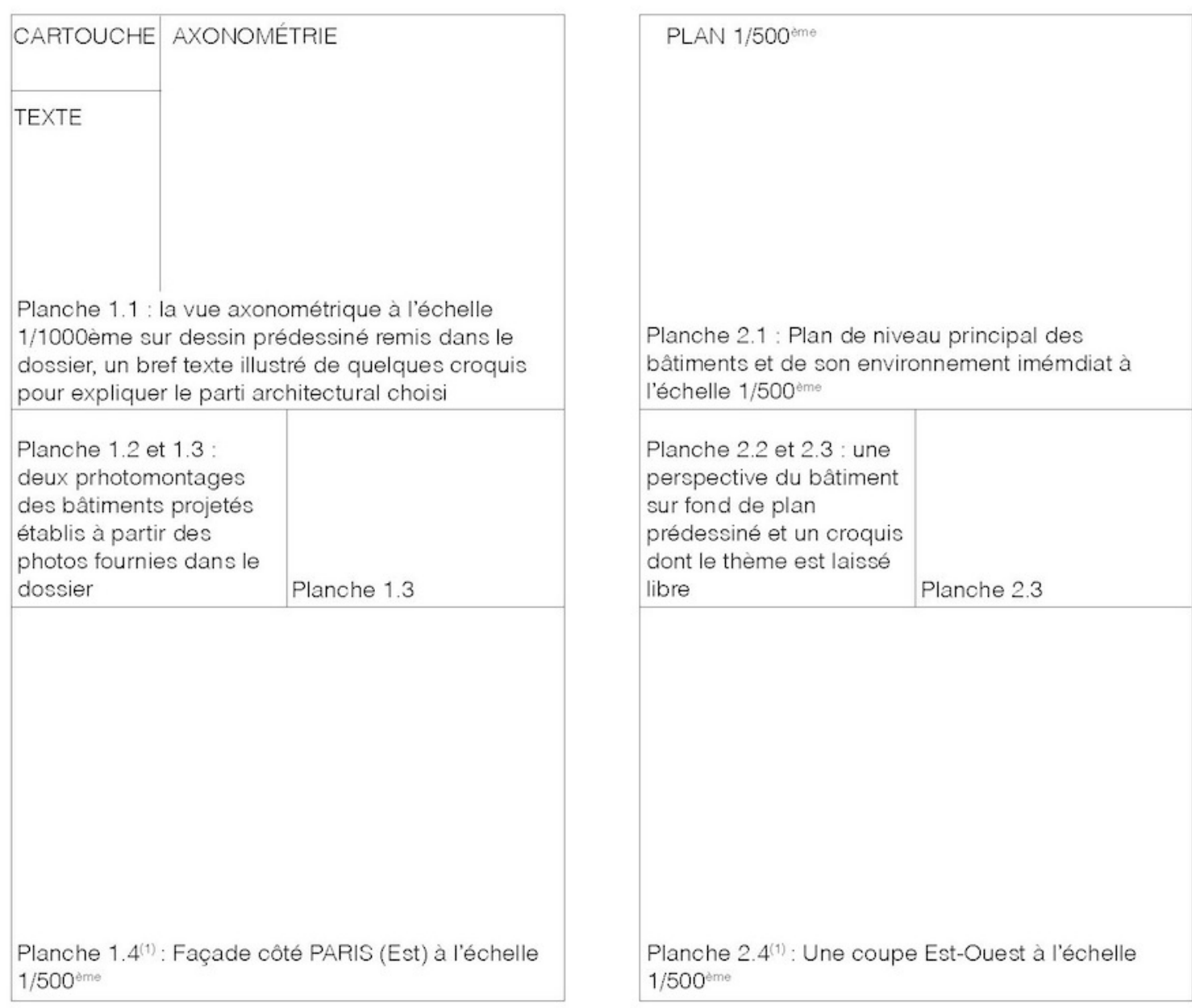

Figure 9: Predefined layout for the competition rendering (Based on EPAD, 1982).

\section{An imposed form?}

The programme reveals several key points. In particular, the history of the axis and of the urban plan and the "problem of the Tête Défense" were described in detail at the beginning of the programme, giving a clear idea of the challenge ahead. The axis was clearly the main issue: "Of all these axes, none is more important, richer in historic symbols, dearer to the hearts of Parisians, more spectacular for the visitor, than the greater western axis [...]". The "planning data" stated the demands for "monumental and expressive" projects slightly more precisely (EPAD, 1982).

The question of whether to close off or open the axis remained unanswered, but it was specified on one point that, historically, it was supposed to stay open ("The historical axis could thus continue on freely"). Yet, at that point, it was considered "appropriate to end one perspective and open up another. The problem of the Tête-Défense therefore is not whether to close off or open an existing perspective: it is to place a landmark on the historical axis [. . .]". The authorisation was given to build above 35 metres (the height at which the construction would become visible under the Arc de Triomphe) for the project itself or for "a monumental signal", under the condition that it be of "very high quality". The project was going to be "a monument". Regarding its volume, the most striking indication was that its "main problem [...] concerns the way of taking into account the historical axis. The monuments on this axis [. . .] all have an empty space at their centre, which all play an essential monumental part [. . .] in the staging of the successive landscapes on the axis. [. . .]". They all follow "the tradition of the grandes compositions of the French" which one can assimilate with symmetry. Finally, on 
a technical level, and though the square allowed for a great liberty of shape, the contestants were reminded to verify where the existing infrastructures were so as not to have all the bearing points on them. But the underground roads were themselves along the axis (Figure 10) (EPAD, 1982).

It is difficult today not to see in these key points a description of the Grande Arche. But that would be forgetting the 400 or so other projects, of which many were also arches. The technical commission noted this in its report. The usual shapes were categorised as "porticos, towers, spheres, pyramids, amphitheatres", often visible under the Arc de Triomphe, and "a great majority of these have in mind the creation of a new arch with a central part open west, or the creation of a simple geometric shape [. . .] on the historical axis" (EPAD, 1983d). These other arches were present even among the honourable mentions and the laureates. ${ }^{19}$ Other projects that were not selected were actually very close to the shape of the winning project or were simply enlarged arcs (Figure 11). ${ }^{20}$ We can say that the main idea for the shape of the Grande Arche was in the spirit of the era and had been for some time in several architects' heads.

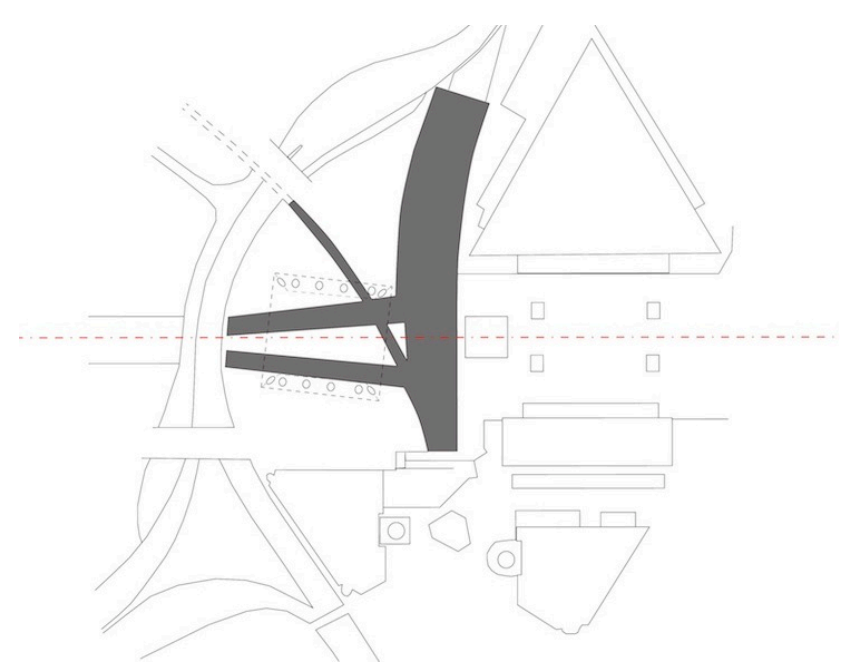

Figure 10: The foundations of the Grande Arche superimposed on the underground roads along the axis (Document: Loïse Lenne. Data: EPAD/Defacto). 

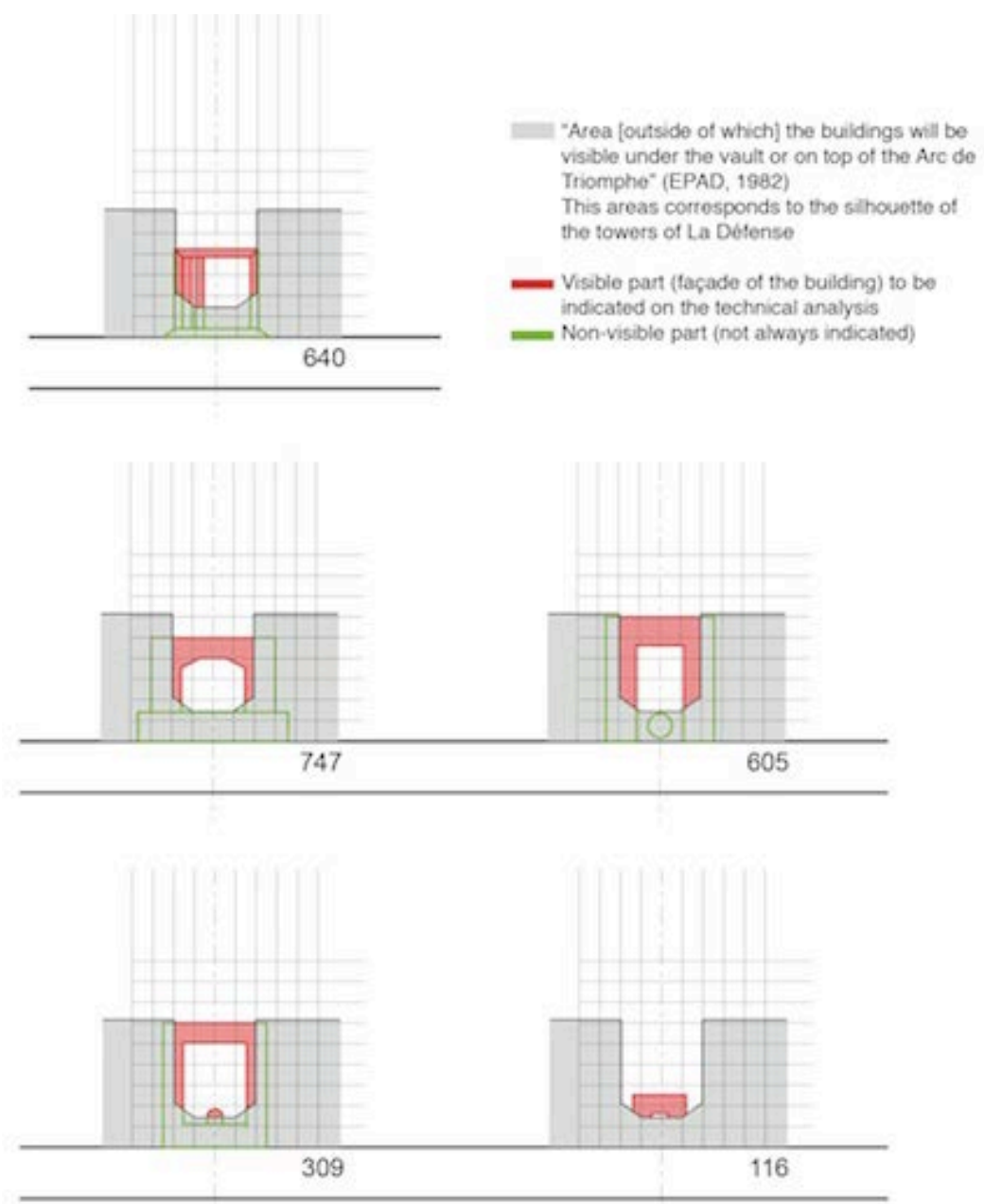

Figure 11: Schemes of analysis by the technical commission. Profile of the winning scheme (640) and projects 116, 309, 605 and 747, as examples (Document: Loïse Lenne. Data: EPAD/Defacto).

\section{Interpreting the programme}

The classification - portico, towers, etc. - established by the technical commission was followed during the ruling, even though Richard Rogers stated at that time that it was "only a mental approach" (Thurnauer, 1983a). With it, the jury intellectualised the projects. All these points allow us to confirm the influence of the jury and the specificity of what happens in a jury room, where the jury "conceives” the project (Chupin, 2012).

But just like for the Lloyd's, the system goes both ways. In fact, Spreckelsen understood and synthesised the demands of the programme and showed it with his text on "An open cube. A window to the world [...] THE TRIUMPHAL ARCH OF MAN", ${ }^{21}$ an expression that the jury would use in its report, just like all the poetic arguments put forth by the architect. The jury even added some in its report (EPAD, 1983e). For example, the fact that the project was $100 \times 100 \mathrm{~m}$ and pivoted according to the same angle as the Cour Carrée of the Louvre was apparently not mentioned in Spreckelsen's initial report.

The project also had the virtue, in the eyes of the jury, of not being overly costly. Here again, Spreckelsen read the programme intelligently and understood what was important as well as the fact that they "did not really know what they wanted" (Lion, 2012). With the pivoting of the cube, he avoided having foundations in the wrong place.

On the other hand, even though the amount of detail in the programme gave life to it, its major component, the Centre International de la Communication (CIC; International Centre for Communication) remained quite vague. Indeed, what does communication mean? 
Despite a number of analyses, the theme was the least defined of all the Grands Travaux and somewhat an opportunistic choice. Because of the "Partner Organisations" - new companies that were to move into the building - it would be placed at the forefront of the development of communication, and, because of the museum, of its showcasing. But also, the visitors would be at the centre of the world because it was going to be possible to follow all world "events" by simply going to La Défense. ${ }^{22}$ The architect Gérard Thurnauer, a member of the jury for the competition and future advisor for the EPAD, would end up considering the idea too ambitious (Thurnauer, 1988).

In order to understand the choice of this programme, it is necessary to remember a time when computers were starting to be found everywhere. No one yet knew the repercussions that new technologies would have, but their rapid development was becoming obvious and a Centre for Communication was an attempt to be avant-garde. This context made it difficult to make choices in terms of programmes, both for the Lloyd's and for the Tête Défense. In the first case, it was decided to insist on flexibility to compensate for the uncertainty; in the other, the definition remained very vague. Spreckelsen understood that, so he took the liberty not to respect the programme's demands for the surface area. Possibly, he felt that it would not be an eliminatory decision.

Lastly, what apparently made the jury lean towards the Dane's project on the last day was its simplicity. In fact, Antoine Grumbach told the other members of the jury that, according to him, "the public would not understand an edifice whose qualities would be too intellectual. [...] The symbol must be 'obvious' " (Thurnauer, 1983a), just as in the case of the Arche, which was later qualified as "sensitive" by Zehrfuss, who was also in favour of the project, whereas the frontrunners Viguier and Jodry's project was seen as representative of "professionalism" (Thurnauer, 1983b). The challenge here was clearly to convince and seduce through a poetic and pure form that could be understood by all.

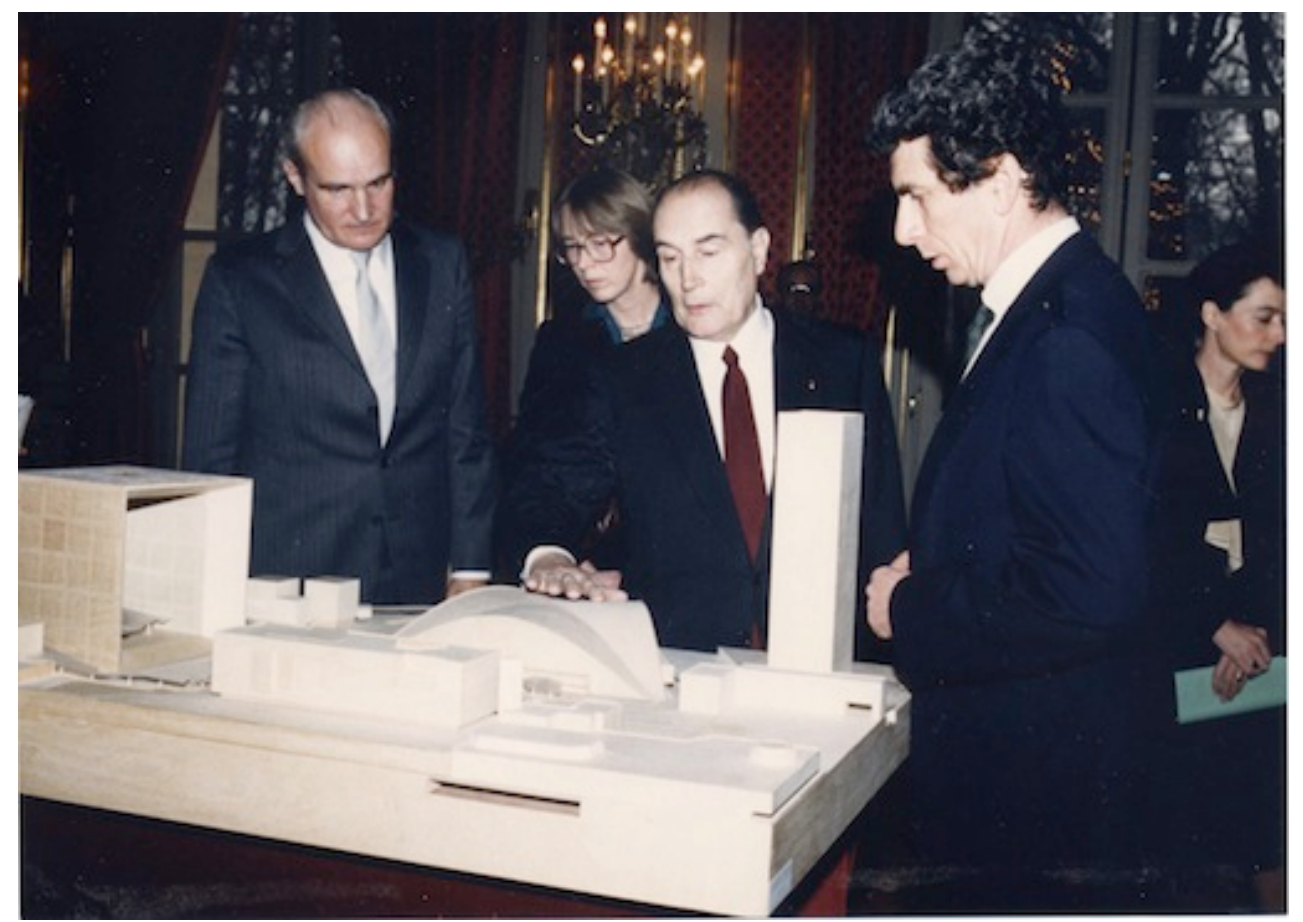

Figure 12a: (from left) J.O. von Spreckelsen, his translator, François Mitterrand and Robert Lion facing a model of the Grande Arche. 


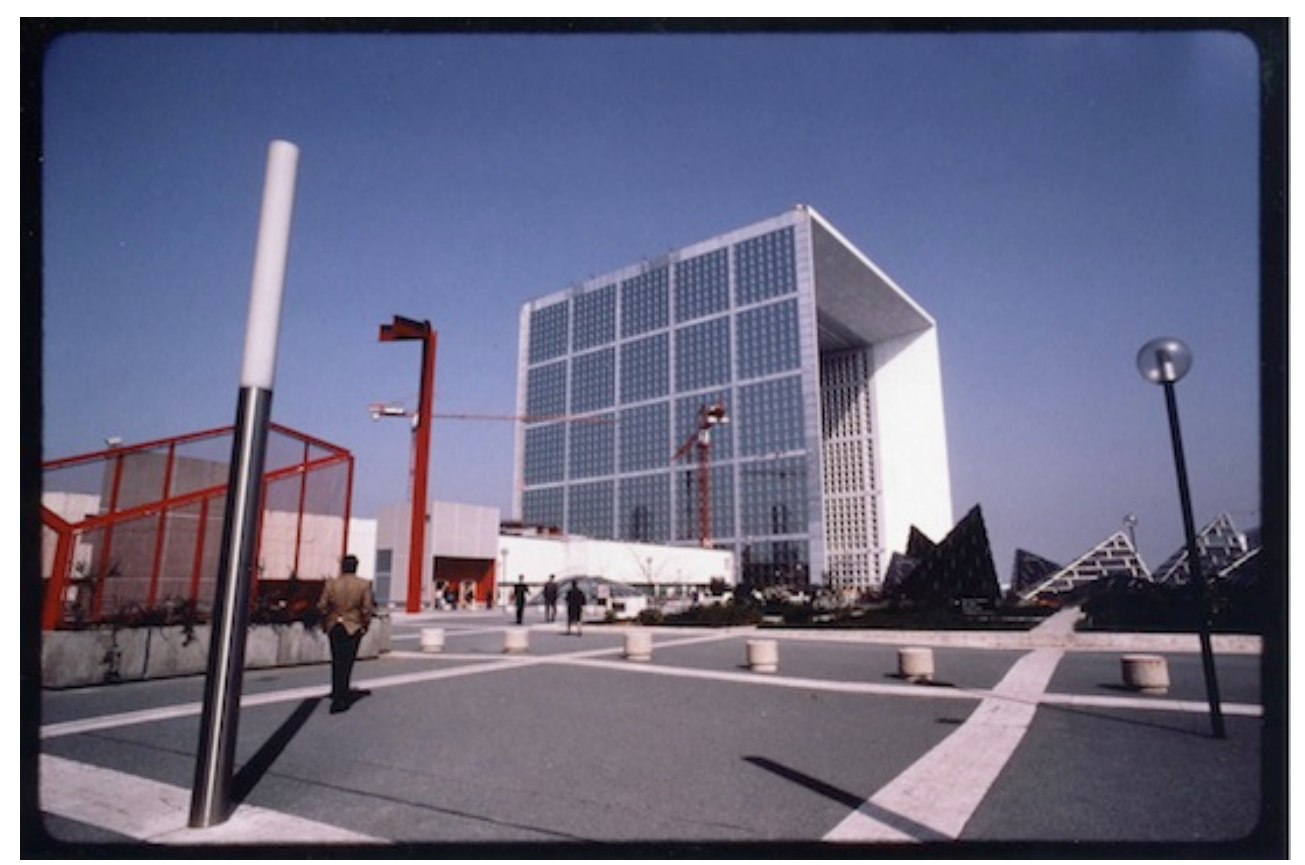

Figure 12b: Comparison with reality, the Grande Arche in 1988 (Copyright: Defacto).

\section{Reaching the client's goal}

Knowing who was the client for the Tête Défense was much more difficult than for the Lloyd's competition. The EPAD prepared the competition but sold the land to the State. The government Ministries (through their unions), and the municipalities (in particular, Puteaux, on which the site lies) would be the future users but were not part of the selection process. However, the final choice was presented to them at the end of jury deliberations. ${ }^{23}$ The main decision-maker was Robert Lion, president of the jury, CEO of the Caisse des Dépots et Consignations (the financer) and future president of the SEM Tête Défense, which was to become, after the competition, the official client (SEM: Société d'économie mixte - a French type of society which involves public and private funding).

But the real client was, in the end, President Mitterrand. Represented by Lion, his aura was clearly palpable. During the jury's sessions, the only real moment of tension that actually occurred was about him - the idea was that the jury would select four projects and that he would make the final choice (Thurnauer, 1983a). Even though the official report does not mention this, the internal notes clearly show that this way of proceeding was controversial, and the members of the jury, especially the British and Americans, rose up against the suggestion that "after working for five days, [they] would allow anyone, even the President, to select” (Rogers, 2012).

Robert Lion insisted during the whole week on letting Mitterrand make the final choice, and even if, today, Richard Rogers seems satisfied with the way they proceeded, we should not forget that the President took almost a month before officially deciding. ${ }^{24} \mathrm{He}$ would ask every person he trusted to come and see the project (Lion, 2012). Mitterrand's choice turned out to be the same as the jury's, although the last race was close between the two front-runners: seven votes for Spreckelsen's project and five for Viguier-Jodry's (Figure 12a).

This anecdote highlights the fact that the story of the jury deliberations is always a rewriting of what really happened. When the story is told, the Grande Arche seems to have been the exception in the conflict that is La Défense, the "new unit" (EPAD, 1982) sought after, the logical and obvious choice coming out of an almost perfect competition. 
However, the jury deliberations during a competition can never be that perfect - they are a moment when opposing ideas are expressed before an agreement is reached. As Rogers puts it, "There was all this discussion; in fact, there was a lot of time to discuss", even though he states that there never was a "minority vote" (Rogers, 2012).

By looking at documents from the jury, we were able, for example, to notice that Spreckelsen's project did not convince the whole jury from the start. Neither was it eliminated, only to be given a second chance like some of the honourable mentions (Tschumi, for example). However, it received only four votes out of 13 the second time the jury voted, when they went from 172 projects to 76. In comparison, the project of Jean-Paul Viguier, Jean-François Jodry and Associates then received 10 votes, and 11 half a day later (against six for the Grande Arche). However, both projects ended on the last day with 12 votes out of 13.

The point here is not at all to put into question the jury's good faith or the quality of its choice, but, on the contrary, to highlight the fact that all competitions are more or less full of debates, which are erased when the result is given out so as to give extra value to the winning project. To quote existing research on the subject of competition, we could say that a jury is a "pedagogical and investigative" situation, where jury members learn more and more about the projects as they select them (Svensson, 2012).

The votes can partly be explained by the quality of the renderings of the two projects. Viguier and Jodry offered detailed designs, in colour, prepared to attract the eye. Spreckelsen's rendering, on the other hand, was composed of quite vague sketches and lacked information. The technical commission even stated in its report that "considering the low level of definition of space, it seems difficult to check the adherence to the program and the functionality of the project” (EPAD, 1983c). The jury can therefore be praised for having seen the potential of a project whose presentation was vague.

\section{The competition as a tool}

In both cases, the stakes were high and the pressure was great to select the best project. The client was uncertain of what he wanted - of almost everything for the Lloyd's and of the built result for the Tête Défense. Therefore, the competition was presented as the only solution, the right tool, which seems to have fulfilled the client's ambitions.

Both cases show a great concentration of ideas about the way the competition should be organised and in the response given by the architects. However, the strategies remained very different, and the courses of their development had a considerable influence on the built result. This is linked first to the client's needs. On the one hand, Lloyd's decided to commission a building that would adapt in time so as not to become obsolete as quickly as the previous ones. On the other, the organisers of the Tête Défense competition were aware that the project might lead to a new controversy, as Robert Lion reminded the members of the jury (Thurnauer, 1983a), so they were careful to remain beyond reproach. But it seems to be also very much linked to the client's culture. In the case of the Lloyd's building, the process was a way of achieving a goal, but the quality of the result was what counted. In the case of the Grande Arche, the process was a way of justifying a choice, and sometimes partly a masquerade to hide what could also have been a very centralised decision. Richard Rogers, who also took part in the Tête Défense process as a jury member, summarises one consequence of these attitudes when saying that "the Lloyd's was not like the Pompidou or the Grande Arche in the sense that it was not as specified nor as open as those competitions. 'Open' may be the wrong word. ... The big difference was that, if my memory is correct, the Pompidou competition programme was probably three centimetres thick of paper, whereas the brief for the Lloyd's was only six pages” (Rogers, 2012).

Competitions have proven to be powerful communication tools. They offer a form of justification to the project that is to be built as well as the opportunity to create a certain 
suspense, an expectation, and somewhat of a hype when the results are announced. For the Grande Arche, an exhibit was set up, with debates and publications. The "424 projects for the Tête Défense" (EPAD, 1983g) handed in for the competition were presented. However, according to some documents in the archives, 425 projects were judged. The possible counting mistake made in the beginning and perpetuated made it possible to obtain a number, if not a "round" one, with a welcomed symmetry (4-2-4).

During completion, a person - Youssef Baccouche - was in charge of communication for the project and organised openings to the public right after the inauguration (Lion, 2012). Later, the rooftop was open to the public. We think that these communication tools were, beyond architecture, factors which made it possible for the Grande Arche to be one of the most well-received Grands Travaux by the French public, "the only one that the press and the architects did not criticise" (Lion, 2012).

At Lloyd's, the communication was first internal, expressed within a "very democratic" (Waters, 1985) process, involving a lot of members of the company in all decisions. The flexibility demanded soon became the project's trademark, and even if it was criticised by some, it was put forward in dozens of architectural magazines, and even seen as a "revolution" (Rice, 1986). The fact that the architects were chosen through a competition was recalled as positive: "Richard Rogers + Architects were chosen from an original field of forty architects to create this striking, important, and controversial addition to the London skyline” (Richard Rogers + Architects: Lloyd's of London, 1985).

Being able to recount the story of what happened during the competition - an always rewritten story that gives extra value to the winning project - is very important for the reception of the building. It highlights the built result: Spreckelsen's Grande Arche was presented as the obvious choice, while the competition process at Lloyd's was stressed. Even though, of course, some other characteristics could be investigated - the budgets devoted to them, for example - the competition shows qualities that help the projects become important in the history of architecture as well as in the history of their neighbourhood.

As early as October 1979, Gérard Thurnauer had handed in an analysis about the Tête Défense where it was said that "the search for monumentalism at the Tête Défense must go beyond that of a formal and aesthetic action. To begin closing the axis in purely architectural terms would be going against the experience of La Défense as it was built and is experienced today. It becomes necessary to have a landmark there [...]. To create a real urban event, a monument that generates use and life [. . .]” (Thurnauer, 1979).

In a way, the Grande Arche filled Thurnauer's prophetic expectations and was soon called a monument, ${ }^{25}$ which makes us wonder if it also became the "event" he was calling for. The Lloyd's building itself was called an "event" (Parent, 1986). But this qualification as event raises questions. Though used by architectural critics, this word is badly defined and never well separated from its vague relatives, such as "monument" or "icon”.

\section{The notion of event}

The notion of event is first a historical one and has been the subject of numerous studies, as the historian François Dosse (2010) recently showed. Generally speaking, two tendencies exist. One considers the event only in its original appearance, as a brutal and unexplainable break in time; the other considers the same break to be inseparable from its causes and consequences (see Dosse, 2010).

It is also a notion used in sociology to define the changes in someone's life - what sociology normally does not define, being more interested in patterns (Bessin, Bidart \& Grossetti, 2010). Trying somehow to combine the two, events are also studied in historical sociology: "Whereas a historian may conceptualize temporality 'as fateful, contingent, complex, eventful, and heterogeneous’ (Sewell, 2005, p.11), the historical sociologist strives 
to appreciate all this complexity and yet find patterns by looking across cases [...]" (Clemens, 2013).

In other words, the challenge that the notion of event poses is one of explaining something unpredictable. Even though the event has causes, it can never be reduced to them. These causes themselves cannot be reduced to a chain of facts, one leading to another, and another, leading in the end to the event. They are more comparable to a social context, a network of ideas, people and actions from which an event grows. This is clearly explained by Deleuze when he writes "what is possible does not pre-exist, it is created by the event" (Deleuze, 2003 cited in Dosse, 2010) - the appearance of an event leads the existing facts to be read as causes.

Following the historical tendency, one also has to take into account the consequences of an event, which can build an event $a$ posteriori. For example, concerning September 11th, some causes were revealed to us by geopolitical analysts and the consequences by the media. Even though the secret services may have been able to detect some sort of danger, no one could have predicted what happened. As for Bin Laden - who made conscious use of the media and was very aware of the symbolic aspect of his act - even he could not predict the extent of the repercussions. Even though it was immediately called an event by all television reports around the world, one can consider, going beyond the idea of our "Society of the Spectacle" (Debord, 1967), that they were able to do so because some consequences were already perceptible.

Micro-historians, on the other hand, have tried to show the importance of simple situations, and how eventful - in our words - they can be (for example Ginzburg, 1976). This introduces the notion of the scale of the event, the framework in which the examples are looked at, that has to be defined in order to call a fact an event. When trying to define the event in architecture - a work that, of course, goes far beyond this article ${ }^{26}$ - some points need to be investigated. The creation context of the project is thus regarded as part of the background making the appearance of an architectural event possible, not dismissing, however, the suddenness of the event - the moment where things topple over, which can never be entirely planned. Within this background, the competition, through its nature, which is supposed to be fairer through the multiplicity of ideas that circulate and through its media coverage but also through the necessity for the client to define more clearly his needs, seems to offer an interesting framework.

\section{Historical versus spatial event}

More than 20 years later, the two buildings investigated remain linked to the areas they were built in. The question here is not so much to claim with no further development that these buildings are architectural events, but, in this article, to draw from the hypothesis that they are events, and to then see what type of event they could be, according to the specific context of their competitions.

The Lloyd's building can be first seen as an event in Richard Rogers' life scale because of what such a project represents in an architect's career; however, it's not only that. We could go so far as to say that the somewhat anti-programme enabled the fulfilment of certain of his principles, and therefore influenced the theoretical course of his career. Rogers, who has since built hundreds of thousands of square metres, in fact still quotes the project during his conferences, as he did recently in a lecture given at the MIPIM (The international real estate show for professionals in Cannes, France) (Rogers, 2012).

On another scale, the Lloyd's building contributed to changes in London. Before its construction, few tall buildings had been erected around the axis of Bishopsgate (Figure 13). They were mostly modern office blocks based on square plans with a central core. The major exception was Tower 42 (180 m, 1980), with its plan composed of three "petals" around the 
core, which was not well received. Though not so tall, an atypical building such as the Lloyd's was thus a radical change, "a landmark in the history of City office building" (Worthington, 1986).

The very British character of this high-tech building - a British movement, by a British architect, in the historic centre of the capital city - is not to set apart from this judgment. It gave a new example of a high office building that was different and thus forever changed the face of the Square Mile, as it is called, and made it look like a new "play area" for architects and developers willing to build high. One might not see it nowadays, hidden behind buildings that are increasingly higher, but at that time, it revealed a dynamic that was contained in the City but that nobody was really capable of expecting or designing. In that way, we can say that the Lloyd's building is an event in historical terms, at least on London's scale. "As the only true building of its time in London, Lloyd's will be as much a milestone in the city's cultural history as the works of Wren and Waterhouse” (Cooper, 1986).

The importance of the Lloyd's must also be linked to the process developed here. Such an innovative process, involving the future users - thus making them proud of the result and willing to defend it - and costing lots of time and money may not entirely explain the result, but might have helped the production of an unusual and ahead of - or maybe very much in - its time project.

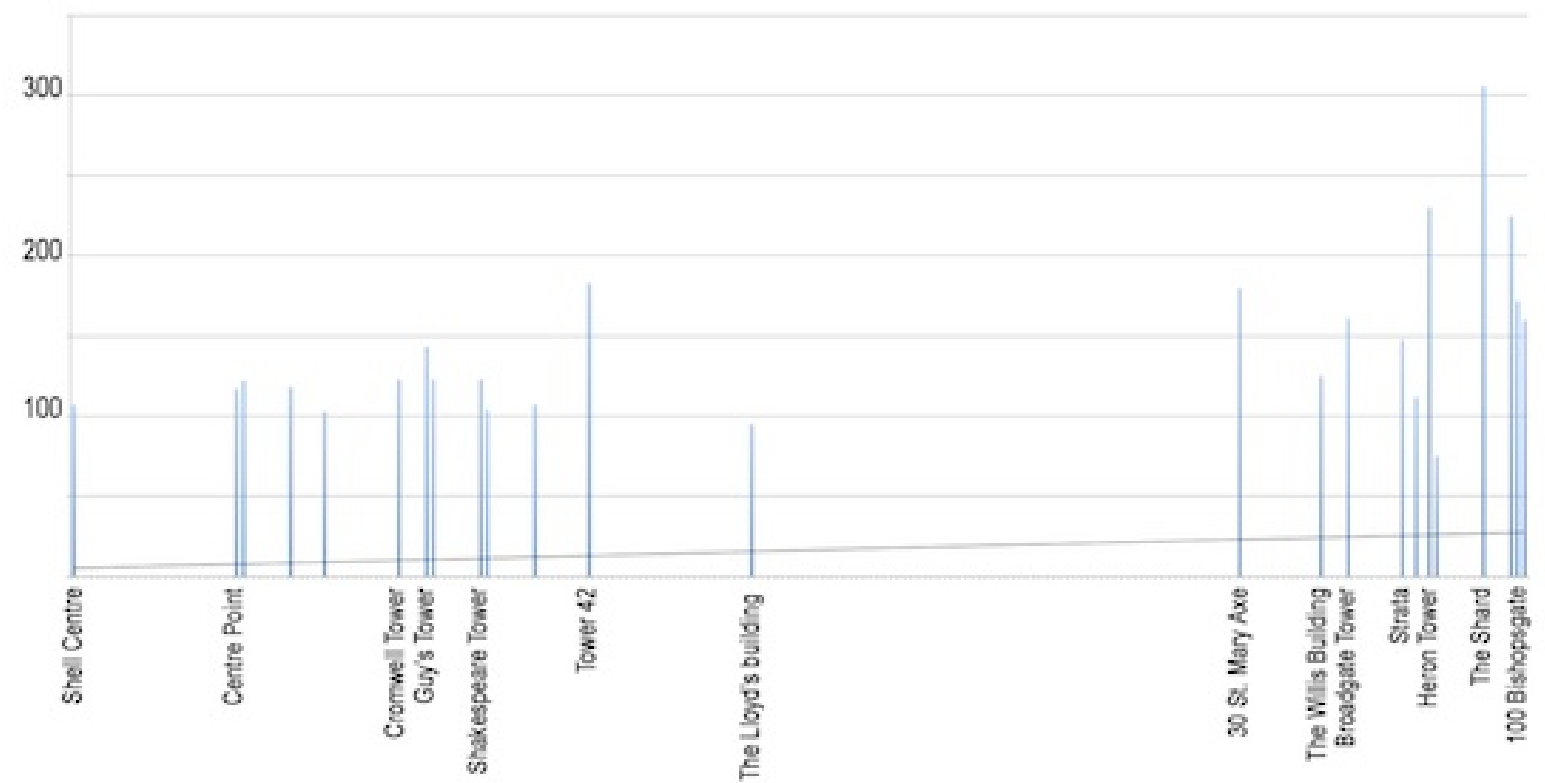

Figure 13: Buildings defined as skyscrapers by the Council on Tall Building and Urban Habitat (CTBUH). Height increases in the central area of London as we have defined it in Figure 5 (Document: Loïse Lenne. Data: CTBUH).

The design was really developed with the client, which avoided many problems and is what makes this competition a unique case. The relation between Spreckelsen and the SEM Tête Défense was quite different. In fact, as we have seen, besides the explicit and already complex client, there also was an implicit one, the French President.

The decisions were therefore much more difficult to make and, according to us, this is why the project, from the start and Mitterrand's validation, did not change a lot, in order to stay as the President wanted it (Figure $12 \mathrm{~b}$ ). As Jean-Louis Subileau, ${ }^{27}$ a major actor in the project, put it: "It is the only monument where the form superseded the content. [. . .] To limit contradiction, we hid behind the masterpiece" (Subileau, 1989). A recent report also states that "its functioning is difficult and its defects, which are due to the fact that the project was chosen for its volume, because the program was specified only after, with respect to the 
winning project, are not easy to correct” (Brodovitch and Vaulont, 2007). The conscious search for a landmark project - and lack of programme - put the functional use of the building in the background.

Still, the Grande Arche has become one of the important monuments of Paris and is a landmark of La Défense and of the capital city. A listing of the Grande Arche was considered as early as 1994, but the EPAD went against it. However, the State has considered selling the Ministries' premises and has therefore recently commissioned a new report, so as to protect the building, which "acquired, from its opening, the status of one of the most exceptional monuments of our country, on a symbolic as well as on an architectural level” (Brodovitch and Vaulont, 2007).

Here, the history of the site played a great role. In fact, the building was built on a historical axis, of which it has become one of the milestones. Each of the developments, from the Cour Carrée of the Louvre to La Défense, is representative of an era, like a constructed timeline.

The shape of the building echoes both the axis and the previous arches. Its spatial answer to the square and the buildings surrounding it, as well as its formal simplicity, overwrites in a way the history - however exciting - of the competition, which is probably not what most will remember. People who work or live at La Défense know the building today as the screen or the stage for entertainment activities and for its steps, which welcome hundreds of people for lunch on sunny afternoons.

Those facts make us think that we are here in front of a different type of event. While for the Lloyd's the framework in which to see it is mostly historical - the Lloyd's as a mark, a break in the course of time - it seems that we are here in front of what we could call a spatial event. The Grande Arche was no revolution in the history of architecture. But its form and the way it was placed are some of the criteria that make this building important in itself, not even as architecture, but as pure form. In that sense, the search for poetry and simplicity during the jury selection was achieved.

We could then go so far as to say that some events can happen, not in time as the historical ones, but in space, creating a new category of "architectural events". Both of these types of event can exist through the construction of a building, and, in both cases, competitions offer tools that help and influence the result in building architecture and in building an event.

\section{Loïse Lenne}

Architect

PhD Candidate at the PRES Paris-Est, OCS laboratory

loise.lenne@univ-paris-est.fr 


\section{List of references}

Bessin, M., Bidart, C., \& Grossetti, M. (Eds.) (2010). Bifurcations. Les sciences sociales face aux ruptures et à l'événement. Paris: La Découverte.

Chupin, J.-P. (2012). Lecture at the international symposium on architectural competitions (L.E.A.P / C.R.C). March 2012, Montreal.

Clemens, E. S. (2013). Toward a historicized sociology: Theorizing events, processes, and emergence. Annual Review of Sociology, 33(2007), 527-549.

Debord, G. (1967/1996). La Société du spectacle. Paris: Gallimard.

Dosse, F. (2010). Renaissance de l'événement, Un défi pour l'historien : entre sphinx et phénix. Paris: PUF.

Foster, N. (1986). Interview by Marc Emery. L'Architecture d'Aujourd'hui, (243), LVII-LX, 1-4.

Ginzburg, C. (1976). Il formaggio e i vermi. Einaudi.

Sewell, W. H. (2005). Logics of history: Social theory and social transformation. Chicago: Univ. Chicago Press. In Clemens. 2013. Toward a historicized sociology: Theorizing events, processes, and emergence. 528531.

Strong, J. (1995). Winning by design - Architectural competitions. Architectural Press.

Strong, J. (2012). The development of the competition system. Lecture at the International Conference on Architectural Competitions, October 2012, Espoo, Finland.

Svensson, C. (2012). Architectural persuasion: On quality assessment in architectural competitions. Nordisk arkitekturforskning, January 2012, 97-207.

\section{Lloyd's}

Appleyard, B. (1986). Richard Rogers. A biography. London; Boston: Faber and Faber.

Blackmore, C. (1990). A client's tale. London: RIBA Publications.

Brown, M. (2011, December 19). Lloyd's building joins Grade I elite at tender age of 25. The Guardian. Retrieved from < http://www.guardian.co.uk/artanddesign/2011/dec/19/lloyds-building-grade-i-elite> [Accessed 12 June 2012].

Cooper, R. (1986). Within these walls. Designers' Journal, (20), September, 48-53.

Davey, P. (1989). Paris 200. The Architectural Review, 186(1110), August.

Fillon, O. (1986). Lloyd's Londres. Architecture intérieure créée, (211), April-May, 94-97.

Lloyd's (2008). Lloyd's, a colorful history. [ppt] London: Lloyd's. Retrieved from < http://www.lloyds.com/The-Market/Tools-and-Resources/Resources/Presentation-Toolkit> [25 June 2012].

Lloyd's (2011). Lloyd's. Cover to cover. [pdf] London: Lloyd's. Retrieved from < http://www.lloyds.com/TheMarket/Tools-and-Resources/Brand-and-Marketing/Cover-to-Cover> [Accessed 25 June 2012].

Lloyd's of London (1987). Architecture \& Urbanism, (3: Richard Rogers Partnership: Lloyd's of London), 3742

Parent, C. (1986). Événement. Lloyd's of London: Richard Rogers Partnership. L'architecture d'aujourd'hui, (247), 2-19

Patronage (1981). RIBA Journal, May 1985.

Rice, P. (1986). Rogers revolution: Lloyd's remarkable new headquarters. Building Design, (807), 32-33.

Richard Rogers and Partners. Architecture and the program: Lloyd's of London (1980). International Architect, 1(3), 25-39.

Richard Rogers + Partners. Lloyd’s new building (1984). Architectural Design, 54(3-4) 65.

Richard Rogers + Architects: Lloyd's of London (1985). Art \& Design, 1(9), October 1985, 38-41. 
Rogers, R. (1988). Order, harmony and modernity. Architecture and Urbanism, extra edition (12, Richard Rogers. 1978-1988), December, 13-32

Rogers, R. (2012). Conference in the MIPIM in Cannes, Qatar pavilion, 6 March 2012.

Stratton, P. M. (1928). Lloyd’s, 1688-1928. The Architectural Review, January, 224-239.

Wall of Light. (1986). Directed by John Tchalenko

Waters, B. (1984). A year at Lloyd's. Building, 247(38), September, 30-37

Waters, B. (1985). The inside story. Building, 249(51), December, 38-41.

Worthington, J. (1986). Beyond the city limits. Designers' Journal, (20), September, 40-47

\section{Grande Arche}

Bernard, C. (1983). Le trou du cube. Le Canard Enchaîné, June 1st.

Brodovitch, M., \& Vaulont, I. (2007). Faisabilité d’une procédure de protection de la Grande Arche. Report $\mathrm{n}^{\circ}$ 004798-01 [pdf] February. [Accessed 16 June 2012].

Charalabidis, C., \& Meurice, Ph. (1981). Flexibilié. Immeuble de la Lloyd’s à Londres : le projet définitif. Techniques et architecture, 337 (Architectures de bureau), September, 52-55.

Chaslin, F. (1989). Un monument en perspective. In: Chaslin, F. et Picon-Lefebvre, V., La Grande Arche de La Défense (pp. 28-29). Paris: Le Moniteur.

EPAD (1980a). Dossier de Consultation pour la Tête Défense. La Défense: EPAD. Archives of the EPAD/Defacto.

EPAD (1980b). Quatre scénarios financiers. La Défense: EPAD. Archives of the EPAD/Defacto.

EPAD (Moritz, M.?), (1981a). Dossier Tête Défense. La Défense: EPAD. September 1981. Archives of the EPAD/Defacto.

EPAD (1981b). Ensemble musical, éléments de programme. 23 November 1981. La Défense: EPAD. Archives of the EPAD/Defacto.

EPAD, (1981c). Quatre scénarios financiers. November 1981. La Défense: EPAD. Archives of the EPAD/Defacto.

EPAD (1982). Competition Program for Tête Défense. La Défense: EPAD. Archives of the EPAD/Defacto.

EPAD (1983a). Letter to Gerard Thurnauer. 26 January 1983. Archives of Gérard Thurnauer/IFA.

EPAD (1983b). Letter to Gerard Thurnauer. 17 February 1983. Archives of Gérard Thurnauer/IFA.

EPAD (1983c). Summary sheet for each project by the Technical Commission. Archives of the EPAD/Defacto.

EPAD (1983d). Technical commission report. April. Archives of the EPAD/Defacto.

EPAD (1983e). Jury report. April. Archives of the EPAD/Defacto.

EPAD (1983f). Letter to Gérard Thurnauer. 5 April. Archives of Gérard Thurnauer/IFA.

EPAD (1983g). 424 projets pour Tête Défense. Concours international d'architecture. Exhibiton from May to July. Archives of the EPAD/Defacto.

La Grande Arche. sd. Brochure published by the EPAD, ca. 1989.

Lacaze, J.-P. (1994). Interview. In: Beauchard, J., Historiographie de la Défense. Unpublished. Archives of the EPAD/Defacto.

Lacaze, J.-P. (2009). Interview by Thierry Paquot. Urbanisme, (366), Retrieved from < http://www.urbanisme.fr/issue/guest.php?code=366> [Accessed 22 April 2012].

Lion, R. (1981). Sam’suffit à la Défense. Le Monde, 12 February.

Lion, R. (1994). Interview. In: Beauchard, J., Historiographie de la Défense. Unpublished. Archives of the EPAD/Defacto. 
Picon-Lefebvre, V. (2012). Grande Arche. In: Chabard, P. and Picon-Lefebvre, V., La Défense : Acteurs, Idées, Projets. Un Dictionnaire Historique. Marseille: Parenthèses.

Rouyer, R. (2012). Tête Défense. In: Chabard, P. and Picon-Lefebvre, V., 2012. La Défense : Acteurs, Idées, Projets. Un Dictionnaire Historique. Marseille: Parenthèses.

Subileau, J.-L. (1989). Pour la noblesse de l'architecture. Discussion with Jean-Louis Subileau. In: “La Grande Arche”, L'événement média, (pp. 16-17). Archives of the EPAD/Defacto.

Thurnauer, G. (1979). Réflexions sur le projet Tête Défense. 1 October. Archives of Gérard Thurnauer/IFA.

Thurnauer, G. (1983a). Handwritten notes. 25-26 April 1983. Archives of Gérard Thurnauer/IFA.

Thurnauer, G. (1983b). Handwritten notes for the jury report. 26 April. Archives of Gérard Thurnauer/IFA.

Thurnauer, G. (1988). Tête Défense et son environnement. October 1988. Archives of Gérard Thurnauer/IFA.

\section{Interviews conducted by Loïse Lenne}

The author would like to thank here all the following persons who have graciously given their time and precious information for this research.

Castro, M. (2012). Mac Castro has been the Events \& Visits Manager at Lloyd's Corporate Communications since 2007. 24 September 2012, 60 min., informal discussion during a personal visit of the Lloyd's building.

Finch, P. (2012). Paul Finch (born in 1949), is the former editor of the Architectural Review and chairman of CABE (the UK Government's Commission for Architecture and the Built Environment). 6 March 2012, 90 min., at the MIPIM (The international real estate show for professionals in Cannes, France), behind the Pipers' model of the City of London in the London pavilion. Questions concerned the roles of the different decision-makers in London, about his role as an editor.

Lion, R. (2012). Robert Lion (born in 1934) is a high-ranking civil servant of the French Government. He was one of the right-hand men of President Mitterrand and CEO of the Caisse des Dépôts et Consignations from 1982 to 1992. 5 September 2012, 90 min. Questions about La Défense, the Grande Arche, and the Tête Défense competition.

Rees, P. W. (2012). Peter Wynne Rees (born in 1948), has been the City planning officer since 1987 (Controller of Planning since 1985) and director of the British Council for Offices since 1990. 7 March 2012, 50 min., at the MIPIM. Questions concerned the decision to build towers in the City and about the Lloyd's building.

Rogers, R. (2012). Richard Rogers (born in 1933) is the architect of the Lloyd's building. 13 June 2012, 40 min., Paris-London. Questions concerned the Lloyd's and his role as a jury member for the Tête Défense project.

Smith, C. (2012). Chris Smith has been the national planning director of English Heritage since 2010 (joined EH in 1994). 6 March 2012, 80 min., at the MIPIM. Questions concerned the role of EH, the Lloyd's building being listed grade I and the roles of the different decision-makers in London.

\section{Notes}

\footnotetext{
${ }^{1}$ According to the Council on Tall Building and Urban Habitat (CTBUH).

${ }^{2}$ Here, the author would like to thank Jean-Marc Lefevre, Johan Huynh and Virginie Pontallier (Defacto) for their great help.

${ }^{3}$ According to Lloyd's (2008), the first known reference to the Coffee House on Tower Street was found in the London Gazette from 18-21 February 1688.

${ }^{4}$ Those two visits from members of the Royal family were filmed and are available at $<$

http://www.lloyds.com/Lloyds/About-us/The-Lloyds-building/History-of-lloyds-buildings>. Accessed August 2012.

${ }^{5}$ Ian Findlay (1918-2002) was chairman of Lloyd's.

${ }^{6}$ Gordon Graham (1920-1997) was and architect. He was president of the RIBA from 1977 to 1979.

${ }^{7}$ Currency of the time.

${ }^{8}$ Courtenay Blackmore (1922-1992) joined Lloyd’s in 1971.
} 
${ }^{9}$ Robert Bordaz (1908-1996) was a high-ranking civil servant appointed by President Pompidou for the completion of the Centre Pompidou.

${ }^{10}$ Peter Green (1924-1996) was chairman of Lloyd's and chairman of Redevelopment Committee.

${ }^{11}$ Under the recommendation of English Heritage, the Heritage Minister, John Penrose, listed the building on 19 December 2011.

12 "It is one of only a handful of postwar buildings and structures to be given Grade I listing, joining Basil Spence's Coventry Cathedral (listed in 1988) Norman Foster's Willis Corroon Building in Ipswich (listed in 1991) and the Severn Bridge (listed in 1998)" (Brown, 2011).

${ }^{13}$ The lease is supposed to end in 2031, but they are already discussing with the tenants what will happen next (Castro, 2012).

${ }^{14}$ The name Tête Défense appeared with Pei’s project in 1969 (Chaslin, 1989).

15 Jean-Paul Lacaze (born in 1930) was director of the EPAD from 1979 to 1984.

${ }^{16}$ The Ministry of Urbanism and Housing and the Ministry of Environment. See the very positive report by Louis Moissonnier (1982).

${ }^{17}$ Currency of the time (EPAD, 1982).

${ }^{18}$ Oriol Guardiola Bohigas (Spain), Kisho Kurokawa (Japan), Richard Meyer (United States) and Richard Rogers (United Kingdom); Antoine Grumbach, Gérard Thurnauer and Bernard Zehrfuss; the economist Mahdi Elmandjra (Morocco), the Mayor of Madrid E. Tierno Galvan (Spain), replaced by his deputy, the UIA delegate and professor Jorge Glusberg (Argentina) and the architecture critic Ada Louise Huxtable (United States); Robert Lion, Serge Antoine and Louis Moissonnier (EPAD, 1982)

${ }^{19}$ Viguier and Jodry proposed a portico closed by a screen; Gregotti, a window pierced into an office building; Nouvel and his partners' grid could also be assimilated to a portico; Autran and Macary designed an asymmetrical arch; Jourda and Perraudin, two blocks forming a door with a glass roof in between; etc.

${ }^{20}$ Projects 112, 116, 209, 401, 407, 431, 530, 605, 647, $742 \ldots$ for the first category. Projects 126, 141, 306, 404, 538, 847 ... for the second.

${ }^{21}$ First lines of the text in Spreckelsen's project ( $n^{\circ} 640$ ) (Archives of the EPAD/Defacto).

${ }^{22}$ One of the functions of the CIC is described in those words in the competition program (EPAD, 1982): "Event/Activity To allow the general public to be in contact with the world and its regions in no time and at any hour". "Event” is of course not to be understood under the exact same definition as the one we will use at the end of the paper.

${ }^{23}$ Respectively, 27 and 29 April 1983, from letters sent to Gérard Thurnauer (EPAD, 1983f).

${ }^{24}$ The projects were presented to Mitterrand on 28 April, but the "Statement from the President", which announced the results, was published on 25 May (Archives of the EPAD/Defacto).

${ }^{25}$ For example, the jury stated that "The fragile balance between the permanent character of the portico and the transient nature of the low-rise constructions forms a contemporary response to the idea of monumentality" (EPAD, 1983e). The EPAD published a text about "the origins of the monument” (La Grande Arche, sd.). The Canard Enchaîné ironically wrote that it would now be impossible "to conceive a monument without a hole in it" on the axis (Bernard, 1983).

${ }^{26}$ And is in fact the subject of the PhD research I am currently working on, directed by Antoine Picon and Pierre Chabard at OCS (Pres Paris-Est).

${ }^{27}$ Jean-Louis Subileau (born in 1943) is an urban planner. He was the director of a commission in charge of the Grands Travaux from 1982 to 1986, and the director of the SEM Tête Défense from 1986 to 1991. 